\title{
ACCOUNTABILITY PARTNERS: LEGISLATED COLLABORATION FOR HEALTH REFORM
}

Mark T. Morrell and Alex T. Krouse ${ }^{1}$

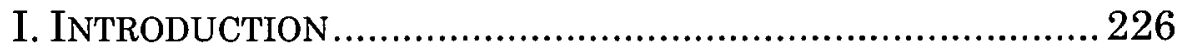

II. PatiEnT ACCOUnTABILITY ............................................. 236

A. Shifting Role of Physician-Patient Relationship.......237

B. Accountability for Rising Patient Care Costs............239

C. Models of Cost Containment Before the Affordable

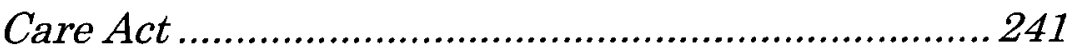

D. Accountability to Patients for Cost Containment Under Affordable Care Act ................................................. 244

E. Toward Patient - Centered Medicine and Consumer

Driven Choices......................................................245

F. Patient-Centered Medical Home Model.....................2247

G. Patient-Centered Outcomes Research Institute .......248

H. Promoting Accountability in Personal Healthcare

Decisions ...............................................................2249

III. COMMUNITY ACCOUNTABILITY.........................................2 252

A. Community Health Centers ....................................2254

B. Transitioning Patients from Hospitals Back to the Community ..........................................................259

C. Accountability of Exempt Hospitals to Their

Communities...........................................................263

IV. ACCOUNTABILITY TO GOVERNMENT ………………….....268

A. Health Insurer Accountability ...................................2269

B. Fraud and Abuse Promoting Accountability .............2275

C. Physician Accountability and Conflicts of Interest ... 280

V. ACCOUNTABILITY AMONG PROVIDERS ...............................28

A. A Brief History-U.S. Health System as a Fragmented

1 Mark T. Morrell is a healthcare attorney in Franklin, Tennessee. Mr. Morrell graduated from Ball State University with a degree in finance (1997), and from Regent Law School with a juris doctor (2001). He is licensed to practice law in Indiana, Virginia and Washington, D.C. Alex T. Krouse is a healthcare attorney with the firm of Krieg DeVault, LLP, located in Mishawaka, Indiana. Mr. Krouse graduated from DePauw University with a degree in history (2008) and from Indiana University with both a juris doctor and a Master in Health Administration (2012). 
Model.

B. Promoting Accountability Among Providers

C. Strengthening "Primary Care".

D. Payment Models Promoting Accountability Among Providers.

E. Organizational Accountability....

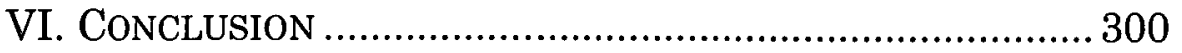

\section{INTRODUCTION}

The term "accountability partner" carries various meanings, depending on the context. It is sometimes associated with weight loss and fitness, as depicted on the reality television show The Biggest Loser. ${ }^{2}$ In financial planning, the term means someone who is responsible for overseeing the spending of another. ${ }^{3}$ The term can refer to an individual who is assigned to assist a prisoner before the prisoner's release back into the general population. ${ }^{4}$ In its

2 In 2013, NBC included The Biggest Loser in its lineup for its fourteenth season in primetime television. See The Biggest Loser - All Bios, NBC, http://www.nbc.com/the-biggest-loser/about/ (last visited Dec. 26, 2013). As a spinoff to the television show, the website http://www.biggestloser.com/ provides tips for sustaining weight loss, including use of accountability partners. See also AMY PARHAM, 10 LESSONS FROM A FORMER FAT GIRL 41 (2010) (former contestant on The Biggest Loser discussing use of an accountability partner). For other examples of accountability in weight loss and fitness, see Heather Caliendo, Tulsa Tough Founder Peddles Fitness, J. REC. (Jan. 23, 2009), http://journalrecord.com/2009/01/23/tulsa-tough-founder-peddles-

fitness/; Diane Carbonell, Weight Loss Tracker Program, LIVESTRONG.COM, http://www.livestrong.com/article/295435-weight-losstracker-program/\#ixzz1dDn1w9ik (last updated Oct. 21, 2013).

3 See, e.g., Myriam DiGiovanni, FORUM Basks in Success of SaveItUp Program and Gears $U p$ for Next Year, CREDIT UNION TIMES (Nov. 18, 2009), http://www.cutimes.com/2009/11/18/forum-basks-insuccess-of-saveitup-program-and-gears-up-for-next-year.

4 See, e.g., Lynn S. Branham, The Mess We're in: Five Steps Towards the Transformation of Prison Cultures, 44 IND. L. REV. 703, 724 (2011). 
most general sense, the term "accountability partner"5 means a person who agrees to accept responsibility and account for another's actions with the purpose of achieving specific, identifiable behavioral goals such as abstinence, temperance, financial stewardship, or avoidance of addictions. ${ }^{6}$

Following enactment of the Patient Protection and Affordable Care Act (the "Affordable Care Act") in March

5 Our description of the term "accountability partner" incorporates a portion of the dictionary definition of the word "accountability." Accountability Definition, MERRIAM-WEBSTER, http://www.merriam-webster.com/dictionary/accountability (last visited August 15, 2013) ("the quality or state of being accountable; especially: an obligation or willingness to accept responsibility or to account for one's actions.").

6 Carol Sanger, Infant Safe Haven Laws: Legislating in the Culture of Life, 106 CoLUM. L. REV. 753, 816-817 (2006) ("[M] wear silver rings 396 and exchange pledges of abstinence with "accountability partners."); Karen Crouse, The Clean and Sober Batting Champion, N.Y. TIMES, Oct. 30, 2010, at D1 (discussing Josh Hamilton's battle with temptation regarding drugs and alcohol and his reliance on "a great accountability partner on the road"); John Leland, The Other Porn Addicts, N.Y. TIMES, May 3, 2010, at A13 (use of a workbook that "emphasizes prayer, Christian fellowship and the use of 'accountability partners' to hold the users to high standards of abstinence"); Michelle Singletary, Sink Your Teeth into a Fast; $A$ Financial Fast, That IsThree Weeks of Buying What You Need but Forgoing the Things You Merely Want, WASH. POST, Jan. 3, 2010, at G01, ("men and women who are good stewards over their personal finances become accountability partners for members who are struggling"); Stephanie Simon, Learning to Write Their Love, L.A. TIMES, Nov. 24, 2005, at A1 ("Many congregations assign men "accountability partners" to keep them on track in love and life."); Jill Sundby, State Bar News: At the Annual Meeting: McShane's Helping Montana Lawyers Tune Up Their Lives' Anthems, 26 MONT. LAW. Oct. 2000, at 18, 20 ("Set up a timeline and have an accountability partner to see that you do it."); Michael Staver, Nine Good Ways to Avoid Burnout, PRINCIPAL's REP., May 2006, at 9, 9 ("Get an 'accountability partner' to help you stay focused."); Ben G. Pender II, Symposium: Financial Compliance, Regulation, and Risk Management: Invigorating the Role of the In-House Legal Advisor as Steward in Ethical Culture and Governance at Clientbusiness Organizations: From 21st Century Failures to True Calling, 12 DuQ. BUS. L.J. 91, 124 (2009) ("The legal advisor as truth-teller is not the pejorative tattletaler/whistleblower. Rather, such a counsel is a trusted advisor, team player, and accountability partner."). 
2010,7 the popular discussions and attention-grabbing headlines ${ }^{8}$ contained within the 400,000 words and 900 pages $^{9}$ of laws and regulations centered around a few repeated, contested issues. Pundits and politicians debated the merits of the "individual mandate," which requires individuals to purchase health insurance and threatens financial penalties for those who refuse. ${ }^{10}$ Americans were (and continue to be) philosophically divided about whether individual consumers should be required to obtain health insurance. ${ }^{11}$ Many question whether the government has

7 Patient Protection and Affordable Care Act of 2010, Pub. L. No. 111-148, 124 Stat. 119-1025 (2010) (amending Title XVIII of the Social Security Act, 42 U.S.C. $§ 1395$ et seq., by adding new $\S 1899$ ) was amended by the Health Care and Education Reconciliation Act of 2010 , Pub. L. 111-152, 124 Stat. 1029-84 (2010). The final amended legislation will be referenced throughout this article as the "Affordable Care Act."

8 See, e.g., Edward Zelinsky, The Individual Mandate Won't Work, HufF Post Politics: THE Blog (July 3, 2012, 1:16 PM), http://www.huffingtonpost.com/edward-zelinsky/the-individual-

mandate-wo_b_1646791.html; Nina Owcharenko, The Case Against Obamacare: Health Care Policy Series for the 112th Congress, HERITAGE FOUND. (Nov. 9, 2010), http://thf_media.s3.amazonaws.com/ 2011/pdf/TheCaseAgainstObamacare.pdf; Lee Sheppard, The Unconstitutional Individual Mandate, ForBES (Sept. 30, 2010, 4:00 PM), http://www.forbes.com/2010/09/30/health-care-mandate-opinionscolumnists-lee-sheppard.html; but see, e.g., Laura Chapin, Republicans Are Hypocrites on Healthcare Individual Mandate, U.S. NEws: NEwS OPINION (Dec. 17, 2010), http://www.usnews.com/opinion/blogs/laurachapin/2010/12/17/republicans-are-hypocrites-on-healthcare-invidualmandate.

$9 \quad$ Varying public reports about the length of the Affordable Care Act ranged from 900 to 2700 pages and from 300,000 to 420,000 words. See, e.g., Tom Giffey, Is 'Obamacare' Really That Long?, LEADER$\begin{array}{lllll}\text { TELEGRAM (July } 17, & 2012,01 & \text { PM), }\end{array}$ http://www.leadertelegram.com/blogs/tom_giffey/article_c9f1fa54-d04111e1-9d01-0019bb2963f4.html.

1026 U.S.C. $\$ 5000$ A (2013). Subtitle F of the Affordable Care Act is aptly titled in common accountability terms: "Shared Responsibility for Health Care."

11 In two separate 2012 Gallup polls, approximately half of Americans supported the Affordable Care Act, and approximately half would like to see it overturned. See Lydia Saad, Americans Issue Split Decision on Healthcare Ruling, GalluP Politics (June 29, 2012), 
the constitutional authority to require an American to buy health insurance. ${ }^{12}$

When the United States Supreme Court effectively upheld the individual mandate under the federal government's authority to enact a tax, it affirmed that Americans would be held accountable for obtaining their own health insurance. ${ }^{13}$ The Supreme Court decided that although the individual mandate is impermissible under the Constitution's Necessary and Proper Clause, ${ }^{14}$ the requirement for nearly all Americans to secure insurance beginning in 2014 is permissible under Congress's taxing authority. ${ }^{15}$ Despite the finality of the Supreme Court's decision, the ruling did not eliminate the ongoing debate about the merits of the Affordable Care Act or the constitutionality of the individual mandate. ${ }^{16}$ The

http://www.gallup.com/poll/155447/Americans-Issue-Split-DecisionHealthcare-Ruling.aspx?utm_source=alert\&utm_medium=email\& utm_campaign $=$ syndication\&utm_content $=$ morelink \&utm_term $=\mathrm{All} \% 20$ Gallup\%20Headlines\%20-\%20Politics; Jeffrey $M$. Jones Americans Divided on Repeal of 2010 Healthcare Law, GALluP POLITICS (Feb. 27, 2012), http://www.gallup.com/poll/152969/Americans-Divided-Repeal2010-Healthcare-Law.aspx.

12 See e.g., Terence P. Jeffrey, Sen. Hatch Questions Constitutionality of Obamacare: If Feds Can Force Us to Buy Health Insurance 'Then There's Literally Nothing the Federal Government Can't Force Us to Do,' CNSNEWS.COM (Nov. 1, 2009), http://cnsnews.com/node/56447. Id.; see also William Dunkelberg, The Supremes Deal A Blow To Small Business, ForBES (June 28, 2012, 5:48 PM), http://www.forbes.com/sites/groupthink/2012/06/28/the-supremesdeal-a-blow-to-small-business/.

13 Nat'l Fed'n of Indep. Bus. v. Sebelius, 132 S. Ct. 2566 (2012).

14 Id. at 2592 ("[T] under the Necessary and Proper Clause as an essential component of the insurance reforms. Each of our prior cases upholding laws under that Clause involved exercises of authority derivative of, and in service to, a granted power.)"

15 Id. at 2600 ("The Affordable Care Act's requirement that certain individuals pay a financial penalty for not obtaining health insurance may reasonably be characterized as a tax. Because the Constitution permits such a tax, it is not our role to forbid it, or to pass upon its wisdom or fairness.")

16 See, e.g., Jason Fodeman, The New Health Law: Bad for Doctors, Awful for Patients, InsTITUTE For HEALTHCARE CONSUMERISM, $\mathrm{http}: / / \mathrm{www}$.theihcc.com/en/communities/policy_legislation/the-new- 
continued existence or possible repeal of the Affordable Care Act was central to the 2012 Presidential election. ${ }^{17}$

In connection with the individual mandate, the Affordable Care Act established a federal healthcare insurance exchange to be a marketplace for making low-cost insurance available to all. ${ }^{18}$ In other words, those who are being held accountable for buying insurance coverage would be offered the opportunity to obtain insurance from these exchanges at an affordable rate. In this way, the government is holding itself accountable to the uninsured consumer. The insurance exchanges, which must be operating in states by January 1, 2014, are expected to be a primary way that the previously uninsured will be able to access affordable insurance coverage to comply with the individual mandate. ${ }^{19}$ While the exchanges will be a major way that as many as thirty million people will obtain

health-law-bad-for-doctors-awful-for-patie_gn17y01k.html (last visited Dec. 27, 2013).

17 Ezra Klein, The Most Important Issue of This Election: Obamacare, WASH. POST: WONKBLOG (Oct. 26, 2012, 11:13 AM), http://www.washingtonpost.com/blogs/wonkblog/wp/2012/10/26/themost-important-issue-of-this-election-health-reform/ ("A vote for Obama is a vote for the law to take effect and for 30 million Americans to get health insurance they won't get otherwise. A vote for Romney is a vote for the law-and its spending and its taxes-to be repealed. There are few elections in which the stakes are so clear."); Sara R. Collins et al, Health Care in the 2012 Presidential Election, CommonwEalTH Fund 9 (2012), http://www.commonwealthfund.org/ /media/Files/Publications/ Fund\%20Report/2012/Oct/1636_Collins_hlt_care_2012_presidential_elec tion_FINAL_CPI_revised_10_02_2012.pdf ("With each candidate offering fundamentally different visions for the nation's health care system, this fall's presidential election provides a stark choice for U.S. voters.").

18 The insurance exchange legislation is found at Subtitle D, Part II, § 1311 of the Affordable Care Act. The title to Part II of Subtitle D acknowledges the accountability of insurance cost savings "Consumer Choices and Insurance Competition Through Health Benefit Exchanges."

19 See generally Joel M. Hamme et al., Health Insurance Exchanges Under the Affordable Care Act: A Primer, 6 J. HEalth \& LIFE SCI. L., June 2013, at 35. 
insurance, ${ }^{20}$ the majority of people overall will continue to get coverage from their employers. ${ }^{21}$

Two kinds of insurance exchanges are authorized under the Affordable Care Act: (i) exchanges for individuals and (ii) Small Business Health Options Program ("SHOP") exchanges for small business owners. ${ }^{22}$ States have authority to decide whether to operate a single exchange to cover both types of services, or to operate interstate exchanges, or to operate exchanges in coordination with the federal government. ${ }^{23}$ If a state elects not to establish an exchange or is unable to have an operational exchange by January 1, 2014, the federal government will operate an exchange for that state. All plans featured on the exchange must cover an 'essential' minimum benefits package that must include ten categories of benefits specified in the Affordable Care Act. ${ }^{24}$ "In a sense, the exchanges are designed to function as a marketplace for health insurance where individuals and small businesses can comparison shop and have ready access to pricing and coverage information."25

Similarly divisive was the requirement that large employers offer insurance to their employees or pay a

20 CBO's Analysis of the Major Health Care Legislation Enacted in March 2010 Before the H. Subcomm. on Health, 112th Cong. 17 (2011) (statement of Douglas W. Elmendorf, Director), available at www.cbo.gov/sites/default/files/cbofiles/ftpdocs/121xx/doc12119/03-30healthcarelegislation.pdf.

21 Alberto R. Gonzales \& Donald B. Stuart, What Implications Will the Supreme Court's Taxing Power Decision Have on the Goals of the Affordable Care Act and Healthcare?, 6 J. HEALTH \& LIFE SCI. L. (SPECIAL ISSUE) 189 (2013) ("For many Americans, the mandate likely will have little impact, as most people will have health insurance from their employer or be covered under a government or public program. Ultimately, about 1 in 10 Americans subject to the mandate will need to decide whether to obtain health insurance coverage or pay the penalty.").

22 Patient Protection and Affordable Care Act of 2010, Pub. L. No. 111-148, § 1311(b), 124 Stat. 119-1025 (2010) (codified as amended at 42 U.S.C. $\S 18031$ (b) (2013)).

23 Id. $\S 1311$ (codified as amended at 42 U.S.C. $\S 18031$ (2013)).

24 Id. $\$ 1302$.

25 Hamme, supra note 19 , at 35 . 
penalty, known as the so-called "employer mandate." 26 Because health insurance coverage is provided by employers for most individuals, and because larger employers are able to negotiate better insurance prices and spread risks more broadly than individuals, the employer mandate was developed as an accountability tool to discourage employers from sending their employees into the newly-formed health insurance exchanges. Employers with more than fifty employees will pay a penalty if an employee receives a federal subsidy to purchase insurance through a health insurance exchange. ${ }^{27}$ Opponents of the employer mandate have suggested that such a requirement will have substantial effects upon employment. ${ }^{28}$ After ongoing debate about the employer mandate, on July 1, 2013, the Obama Administration announced that it is delaying a major provision in the healthcare overhaul, putting off until 2015 a requirement that many employers offer health insurance. ${ }^{29}$

26 Patient Protection and Affordable Care Act of $2010 \S \S 1511-15$ (codified as amended at 29 U.S.C. $\S 218 \mathrm{a}-\mathrm{b}$ (2013), 26 U.S.C. $\S \S 125$, 4980H, 6056, 6724 (2013)).

27 Patient Protection and Affordable Care Act of $2010 \S 1513$ (codified as amended at 26 U.S.C. $\$ 4980 \mathrm{H}(2013)$ ).

28 See, e.g., Nadia Masri \& Sharon F. Fountain, Health Care Reform: What the Employer Mandate Means, 31 TAX MGMT. WKLY. REP. 897 (2012); James A.J. Revels, What Effect Will Health Reform Law Have on Businesses and the U.S. Economy?, PHYSICIANS NEWS DIG. (Aug. 21, 2012, 8:38 AM), http://www.physiciansnews.com/2012/08/21/ what-effect-will-health-reform-law-have-on-businesses-and-the-u'seconomy/; Mark Trumbull, Health-Care Reform Law: How Supreme Court Ruling Affects Families, CHRISTIAN SCI. MonITOR (June 27, 2012), http://www.csmonitor.com/USA/DC-Decoder/2012/0627/Health-carereform-law-How-Supreme-Court-ruling-affects-families (last visited Dec. $27,2013)$.

29 InTERnal REVENUE SERV., DEP'T OF THE TREASURY, Notice

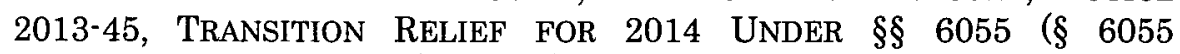
INFORMATION REPORTING), 6056 ( $\$ 6056$ INFORMATION REPORTING) AND 4980H (EMPloyer SHAREd ResPonsibility Provisions) (2013); See also, e.g., JANEMARIE MULVEY ET AL., R43150, DELAY IN IMPLEMENTATION OF POTENTIAL EMPLOYER PENALTIES UNDER ACA, CONG. RESEARCH SERV. (July 22, 2013), http://www.fas.org/sgp/crs/misc/R43150.pdf; Avik Roy, White House To Delay Obamacare's Employer Mandate Until 2015; Far-Reaching 
Amidst the headlines and debates about the individual mandate, insurance exchanges, the employer mandate and other publicized aspects of healthcare reform such as Medicaid expansion, ${ }^{30}$ a significant element of the reform legislation involves less-discussed and less publicly disputed (but perhaps no less contentious) provisions. Many of the provisions in the Affordable Care Act receiving less public scrutiny focused on the systemic goal of providing better healthcare more efficiently, often referred to generally as "accountable care."31 Conceptually, there is generally less debate about this goal because there is more agreement about the goal of improving healthcare and reducing overall costs, which is the commonly understood goal of accountable care.

While party lines are drawn primarily upon the more newsworthy elements of the Affordable Care Act, the daily issues facing healthcare providers and patients directly involve many of these lesser-known, and sometimes lesser understood provisions. ${ }^{32}$ Many of these less-publicized

Implications For The Private Health Insurance Market, FoRBEs (July 2, 2013, 6:21 PM), http://www.forbes.com/sites/theapothecary/2013/07/02/ white-house-to-delay-obamacares-employer-mandate-until-2015-farreaching-implications-for-the-private-health-insurance-market/. But even the delay of the effective date of the provision has been subject to debate. See Fred Lucas, Congress Debates if Obama Could Unilaterally Delay Employer Mandate, CNSNEWS.COM (July 24, 2013, 9:09 AM), http://www.cnsnews.com/news/article/congress-debates-if-obama-couldunilaterally-delay-employer-mandate\#sthash.Qro5L8Jb.dpuf.

30 Where the States Stand on Medicaid Expansion, ADVISORY BOARD COMPANY (Nov. 6, 2013, 5:02), http://www.advisory.com/DailyBriefing/Resources/Primers/MedicaidMap.

${ }^{31}$ See, e.g., Mark Shields, From Clinical Integration to Accountable Care, 20 AnNals Health L. 151 (2011); Elliott S. Fisher et al., Fostering Accountable Health Care, 28 HeAlth AFF. 169, 219 (2009).

32 Some of the less-publicized (and generally less controversial) examples in the Affordable Care Act beyond the individual mandate and insurance coverage provisions include, for example, § 1003 (authorizing the Secretary of the Department of Health and Human Services to review insurance premiums for unreasonable increases); § 2601 (caring for persons eligible for "dual eligibles' who are able to receive both Medicare and Medicaid); 2702 (prohibiting payments for inappropriate diagnoses and treatment); $\S \S 2704-2706$ (projects to test bundled payments, global payment systems, and pediatric accountable care 
topics surround the notion of accountability. Often, these "accountability" provisions engender wider support from a spectrum of political parties. Nearly everyone agrees that the healthcare system needs to be "fixed," but they disagree on the mechanism or method to "fix" it. The Affordable Care Act offered several controversial proposals to revise the system, but also contained within the Affordable Care Act are a large number of other provisions that promote greater accountability for all participants within the system.

In its common meaning, accountability is an optional activity desired by the one seeking to be held responsible. In other words, the person being held accountable has made a choice to participate. However, under the Affordable Care Act, some accountability is optional, but much of the accountability is in the form of legislated accountability. A form of accountability will occur, or the refusing parties will face a penalty. The parties enter into the accountability partnerships willingly at times and, sometimes, unwillingly. Either way, legislated accountability under the reform regime will drive care in the twenty-first century in the United States.

This article discusses how the Affordable Care Act promotes, in some respects, requires physicians, hospitals,

organizations); $\S 3001$ (value-based purchasing of services from hospitals that meet performance standards); $\$ 3006$ (authorizing valuebased payments to skilled nursing facilities, home health agencies, and ambulatory surgical centers); $\S 3007$ (payments adjusted based on cost and quality of care); $\S 3008$ (reducing payments for hospital-acquired medical conditions); $\S 3022$ (shared savings for accountable care organizations that meet quality and cost benchmarks); $\S 3023$ (pilot program for bundled payments); $\S 3024$ (testing payment incentives and service delivery models for primary care); $\$ 3025$ (reducing payments for hospital readmissions of certain conditions); $\S 3140$ (authorizing demonstration projects of hospice program models); $\S 3403$ (forming a Medicare Payment Advisory Board to "reduce the per capita rate of growth in Medicare spending"); $\S 5001-5701$ (incentives offered to students who enter primary care, nursing, geriatrics, public health, and allied health professions); $\S 6001$ (tightening limitations on physician self-referrals); $\S 6301$ (creating an independent Patient-Centered Outcomes Research Institute to study the effectiveness of medical care); $\S 10606$ (increasing penalties for health care fraud). 
ancillary providers, patients, and managed care providers to become accountability partners, often with each other, sometimes with their communities, the government, and their patients. Depending on the context, the accountability partners change. However, in the grand scheme of healthcare, accountability is expected and is the method for pursuing the intention of the Affordable Care Act. ${ }^{33}$

Attempts have been taken by other authors in the United States and internationally to discuss accountability prior to the Affordable Care Act in the context of healthcare. ${ }^{34}$ This article cannot, and is not intended to be, a comprehensive description of every way in which various parties are "accountability partners" under the Affordable Care Act. Rather, the goal of this article is to provide an overview of the manner in which legislated accountability (particularly the less-publicized provisions of the Affordable Care Act) will be the method by which the United States healthcare system collectively will pursue the triple aims that Donald Berwick notably identified during his stint as Chief of the Center for Medicare and Medicaid Services:

1. improving healthcare for individuals;

2. improving healthcare for populations; and

3. reducing per-capita cost of healthcare. ${ }^{35}$

33 See Daniel R. Levinson, A New Era of Medicare Oversight, 15 J. HeAlTh CARE L. \& POL'Y, 249, 262 (2012) ("As Medicare adjusts to the new landscape, it will be critical for program officials and providers to place a sharp focus on ensuring accountability and transparency in the design and operation of these new programs.").

34 See, e.g., Patrick J. Monahan, Chaoulli v. Quebec and the Future of Canadian Health Care: Patient Accountability as the "Sixth Principle" of the Canada Health Act, C.D. HowE INST. (Nov. 29, 2006), http://www.cdhowe.org/pdf/benefactors_lecture_2006.pdf; K J Woods, $A$ Critical Appraisal of Accountability Structures in Integrated Health Care Systems, ScoTTISH HEALTH SERVS. POL'Y F. (Sept. 2002); Ezekial J. Emmanuel \& Linda L. Emmanuel, What is Accountability in Health Care?, ANNALS InTERnAL MED., Jan. 15, 1996, at 229.

35 See, e.g., Donald M. Berwick et al., The Triple Aim: Care, Health, and Cost, 27 HEALTH AFF., May 2008, at 759, available at http://content.healthaffairs.org/content/27/3/759.full.pdf. 
The triple aims have been identified as the systemic goal of healthcare in the United States. This article considers how the method of bringing about systemic changes to the entire healthcare delivery system will be accomplished through various constituencies working together as "accountability partners." There will be familiar accountability partners under the Affordable Care Act, along with some new partners who have not worked together often previously. And these accountability partners, working together through legislatively'mandated relationships, will determine the ultimate success or failure of healthcare reform in the twenty-first century.

Part II will review how the Affordable Care Act requires accountability of providers to patients and of patients for their own care. Part III will discuss how the Affordable Care Act promotes community accountability. Part IV will discuss financial accountability of providers to the government and third party payors. Part $\mathrm{V}$ will discuss accountability of providers among each other.

\section{Patient ACCOUNTABility}

The public, as well as most patients, are familiar with the notion that a physician's first obligation is to "do no harm."36 This basic premise suggests that a healthcare provider must use advanced education, knowledge and skill for the benefit of another party, the patient, without adding risk to the patient's condition. Under this model historically, physicians were assumed by most patients to be delivering medically appropriate care, and patients entered into a relationship of trust and vulnerability that placed the healthcare provider in an immense position of power and

36 Hippocrates, THE CoRPUS, 1-2 (Conrad Fischer ed., 2008); see also Karen H. Rothenberg \& Lynn W. Bush, Manipulating Fate: Medical Innovations, Ethical Implications, Theatrical Illuminations, 13 HoUS. J. HEALTH L. \& POL'Y 1, 8 (2012) (quoting HIPPOCRATES, supra) ("Whereas the Hippocratic Oath espoused the paradigm 'to do good or to do no harm' and Percival's 1803 Medical Ethics expanded on professional virtues to gain public trust, theatre often dramatizes the potential of the disequilibrium in the power relationship between physician-scientists and patient-participants."). 
responsibility. ${ }^{37}$ Indeed, because the physician-patient relationship requires the patient to place confidence and trust in the physician, some courts "apply fiduciary principles to enforce duties involving disclosure and informed consent, patient confidences, and not withholding or fraudulently concealing information patients or related third parties are entitled to receive." 38

Even if the healthcare provider is in a special relationship to the patient, what level of accountability should the provider have for the patient's health outcome? At what cost should a provider be held accountable for the individual health outcome of individuals and populations? Should a provider offer the best possible outcome to every patient, every time, regardless of cost? And from the opposing viewpoint, what role do individual patients have in terms of their own health, particularly when making lifestyle decisions involving tobacco use, alcohol use, diet and exercise? How do these viewpoints work together?

Patient accountability cuts several ways. First, providers are incentivized under the Affordable Care Act to be accountable to patients for clinical outcomes and cost savings. A number of patient-centered efforts have also been initiated to give the patient a more central role in the process. However, patients are also now more accountable for their own care efforts. Collectively, patient accountability is central to the outcomes sought under the Affordable Care Act.

\section{A. Shifting Role of Physician-Patient Relationship}

In recent decades, culminating with the Affordable Care Act, the paradigm for the physician-patient relationship has shifted. For example, a patient is no longer just a patient

37 See generally Dayna Bowen Matthew, Implementing American Health Care Reform: The Fiduciary Imperative, 59 BUFF. L. REV. 715, 746 (2011) ("The resulting vulnerability the patient accepts by placing herself at the mercy of the physicians' exercise of discretion and power contrasts sharply with the superiority of medical knowledge and information the physician has.").

$38 \quad$ Id. at 727. 
subject to the instructions of a physician who must be trusted and whose medical decisions are determinative of patient care. An emerging model of physician-patient interaction is affected significantly by the way healthcare is paid, an approach which "turn[s] patients into consumers by placing them, rather than physicians, insurers, or the government, in the driver's seat for making medical spending decisions." 39 This gradual shift in orientationfrom physician-centered care to patient-centered care-has been well-documented. ${ }^{40}$ The new model of patient care is to put the patient front and center. In fact, the very title of this type of care is known as "patient-centered" care. This is because "[t]he medical profession ... is undergoing a profound transformation with the imperative to deliver more patient-centered care to individuals and populations, improve quality, and reduce unnecessary costs and waste."41

While a primary goal of patient-centered care is to improve clinical outcomes for patients, another equally important purpose of patient-centered care is to achieve greater cost savings on a macro level by developing a system

39 See generally Mark A. Hall, The Legal and Historical Foundations of Patients as Medical Consumers, 96 GEO. L.J. 583, 587 (2008) ("This consumer characterization is the emerging centerpiece of health care policy. Informed by their doctors or by their own research, and activated by their own financial interest, people with consumerdriven health insurance are expected to determine which items of health care are worth the cost and which are not, at each point of purchase in the health care delivery system.").

40 See, e.g., Austin S. Baldwin et al., Preferences for a PatientCentered Role Orientation: Association with Patient-InformationSeeking Behavior and Clinical Markers of Health, 35 ANNALS BEHAV. MED. 80, 80-81 (2008) (studying patient preferences for patient-centered care); Klea D. Bertakis et al., Patient-Centered Communication in Primary Care: Physician and Patient Gender and Gender Concordance, 18 J. WOMEN'S HEALTH 539, 539-40 (2009) (stating that the main methodologies for measuring patient-centeredness are "self-reported assessments ... of the medical encounter and direct observation of the clinical encounter").

41 Paul V. Miles et al., Physician Professionalism and Accountability: The Role of Collaborative Improvement Networks, Pediatrics, 131 AM. ACAD. Pediatrics (SupplemenT) S204 (June 1, 2013), available at http://pediatrics.aappublications.org/content/131/

Supplement_4/S204.full.pdf. 
whereby patients are accountable for their own care and physicians are accountable to patients for the outcomes and for the costs of their care.

\section{B. Accountability for Rising Patient Care Costs}

The dominant model for healthcare payment historically in the United States is a "fee-for-service" model, whereby physicians care for their patients, and, then, bill according to the volume of services provided. ${ }^{42}$ Bills are then payable by the patient, by a third-party commercial payor, or by a governmental program, and sometimes bills are not paid at all and are written off as charity care. ${ }^{43}$ Under this system, the more services provided by a physician, the greater the revenue (and the bigger the bill). Providers are, therefore, incentivized to increase their volume of services as a way to earn greater financial rewards. This model of fee-for-service payment has been challenged as lacking accountability to patients and to the overall system. ${ }^{44}$

The exponential growth rate in healthcare costs in the United States has reached historic proportions. ${ }^{45}$ The rate

42 MEdiCARE PAYMENT ADVISORY COMM'N, REPORT TO THE CONGRESS: PROMOTING GREATER EFFICIENCY IN MEDICARE 63-70 (2007), available at http://medpac.gov/documents/Jun07_EntireReport.pdf.

43 See Thomas L. Hafemeister \& Joshua Hinckley Porter, Don't Let Go of the Rope: Reducing Readmissions by Recognizing Hospitals' Fiduciary Duties to their Discharged Patients, 62 AM. U. L. REV. 513, $576 \mathrm{n} .31$ (2013) ("Traditionally in a fee-for-service payment system, a perverse incentive exists for hospitals to not assist recently discharged patients, as hospitals can receive greater overall compensation if discharged patients relapse and return requiring more services."); see generally Ann Marie Marciarillet, Healing Medicare Hospital Recidivism: Causes and Cures, 37 AM. J. L. AND MED. 41, 72-73 (2011).

44 See generally Glen Cheng, The National Residency Exchange: $A$ Proposal to Restore Primary Care in an Age of Microspecialization, 38 AM. J.L. \& MED. 158, 160 (2012) ("The problems inherent in a fee-forservice reimbursement system, including the lack of quality control and the unbridled ability of providers to determine their own salary, were a significant factor in the rise of managed care organizations and the era of regulated healthcare expenditures.").

45 Mark A. Hal \& Carl E. Schneider, When Patients Say No (To Save Money): An Essay on the Tectonics of Health Law, 41 CoNN. L. 
of growth is higher than both the rate of inflation and the growth rate for national income. ${ }^{46}$ Between 1998 and 2009, the spending on healthcare doubled, and the numbers are so large that they are difficult to conceptualize. ${ }^{47}$ Although the Affordable Care Act was designed to reduce the exponential increase in healthcare costs, calculations prior to the enactment of the Affordable Care Act suggested that the amount of spending in 2019 is expected to double the spending level for 2008.48

One of the concerns with the rising cost of care is that cost does not equal quality. Studies indicate that patients do not always get what they pay for because increasing healthcare costs "do not appear to be correlated with better quality." 49 In fact, compared with other countries, the

REV. 743, 747 (2009) ("Medical spending has outstripped inflation for decades, and for decades, attempts to restrain those costs haveessentially-failed."); see also CTRS. FOR MEDICARE AND MEDICAID SERVS., DeP'T of Health \& Human SeRvs., National Health Expenditures Aggregate, Per CAPITA AMOUnts, PERCENT Distribution, AND Average AnNual Percent Growth, By Source of Funds: SElected CALENDAR YEARS 1960-2009 tbl.1 (2009), available at http://www.cms.gov/NationalHealthExpendData/downloads/tables.pdf; Eric Kimbuende et al., U.S. Health Care Costs: Background Brief, HENRY J. KAISER FAM. FOUND., available at http://www.losangelesdebtresource.com/files/2011/05/www.kaiseredu.org _health-care-costs.pdf (noting that healthcare expenditures have outpaced inflation and income growth).

46 CTRS. FOR MEDICARE \& MEDICAID SERVS., DEP'T OF HEALTH \& Human Servs., National Health Expenditure Projections 20092019 tbl.1 (2009), available at http://www.cms.gov/

NationalHealthExpendData/downloads/proj2009.pdf.

$47 \quad I d$.

48 Id. at tbl.2.

49 MEDICARE PAYMENT ADVISORY COMM'N, REPORT TO THE Congress: Improving InCENTIVES IN THE MEDICARE Program 49, 53 (2009), available at http://www.medpac.gov/documents/

Jun09_EntireReport.pdf; see generally Christopher Smith, Between the Scylla and Charybdis: Physicians and the Clash of Liability Standards and Cost Cutting Goals Within Accountable Care Organizations, 20 ANnals Health L. 165, 167-69 (2011); David A. Squires, Explaining High Health Care Spending in the United States: An International Comparison of Supply, Utilization, Prices, and Quality, 10 Commonwealth FUnD, Issues in International Health Policy, May 2012, at 1, http://www.commonwealthfund.org/ /media/Files/ 
United States spends more of its GDP on healthcare than many other nations, with questionable results in terms of whether better quality outcomes are achieved.50 A recurring question when examining various efforts or payment models is whether higher quality of patient care can lead to both higher quality and can also be delivered at a lower cost. "Whether viewed at the macro' or microeconomic level, healthcare costs are high and getting higher, and the burden on individuals and employers is becoming increasingly heavy. These pressures serve as the genesis for the many of the cost containment efforts within the health care sector."51

\section{Models of Cost Containment Before the Affordable Care Act}

Central to the debate about the merits of healthcare reform is whether a provider can lower cost and still provide the same quality healthcare, which is a fundamental premise of the Affordable Care Act. Even before the enactment of the Affordable Care Act, healthcare providers were developing models of payment to promote high quality and more efficiently priced care. These models typically involved prepaid health plans, where the provider accepted financial risk for the medical outcomes of its enrollees. The concept of prepaid medical plans dates back as early as the nineteenth century, when similarly-situated groups of workers arranged to address the healthcare needs of their groups, such as the mining or railroad workers. ${ }^{52}$

Publications/Issue\%20Brief/2012/May/1595_Squires_explaining_high_hl t_care_spending_intl_brief.pdf.

50 Karen Davis et al., Mirror, Mirror on the Wall: How the Performance of the U.S. Health Care System Compares Internationally, 2010 Update, COMMONWEALTH FUND, June 2010, at 2, http://www.commonwealthfund.org/ /media/Files/Publications/Fund $\% 20$ Report/2010/Jun/1400_Davis_Mirror_Mirror_on_the_wall_2010.pdf.

51 Smith, supra note 49, at 169.

52 A Brief History of Managed Care, Tufts Managed CARE INSTITUTE (1998), www.thci.org/downloads/briefhist.pdf (last visited July 18, 2013). 
More formal prepaid group plans emerged after World War I, followed by the formation of a recognizable health maintenance organization ${ }^{53}$ in the 1940 s, when industrialist Henry J. Kaiser opened his plans to the public after World War II (better known as Kaiser Permanente). ${ }^{54}$ The American Medical Association ("AMA") fought back against the emergence of HMOs, rejecting anything resembling the corporate practice of medicine. ${ }^{55}$ As a result of the pushback against the new plans, the AMA was convicted of violating the Sherman Antitrust Act. 56

In the 1980s HMO membership soared, when employers-the primary funding source for most private insurance in the United States-attempted to reduce the cost of their employees' healthcare. 57 Employers often continued to offer healthcare benefits but switched to HMOs or other forms of prepaid care because they were considered more cost efficient than traditional fee-for-service care. ${ }^{58}$

The model of prepaid health plans began to change in the late 1990s and early 2000s as more Americans were enrolled in preferred provider organizations ("PPOs"). The Medicare Modernization Act of $2003^{59}$ and similar policy changes that facilitate consumer-directed health plans

53 An HMO is "a healthcare system that assumes or shares both the financial risks and the delivery risks associated with providing comprehensive medical services to a voluntarily enrolled population in a particular geographic area, usually in return for a fixed, prepaid fee." Glossory: H, BLUECROSS BLUESHIELD Ass'N, http://www.bcbs.com/ glossary/?firstlet=H (last visited Dec. 27, 2013).

54 TUFTS MANAGED CARE INSTITUTE, supra note 52.

55 Id.

56 Sherman Antitrust Act, 26 Stat. 209 (1890) (codified as amended at 15 U.S.C. $\S \S 1-7$ (2013)); Am. Med. Ass'n. v. United States, 317 U.S. 519 (1943).

57 See Martin Markovich, The Rise of HMOs, RAND CORP., http://www.rand.org/content/dam/rand/pubs/rgs_dissertations/RGSD172 /RGSD172.ch1.pdf.

58 TUFTS MANAGED CARE INSTITUTE, supra note 52.

59 Medicare Modernization Act of 2003, Pub. L. 108-173, 117 Stat. 2066 (2003) (codified as amended at 26 U.S.C. $\$ \S 6103,7213$ (2013), 45 U.S.C. $\S 231 f$ (2013), and scattered sections of 42 U.S.C.). 
("CDHP")60_including health savings accounts61 ("HSA") and health reimbursement accounts ${ }^{62}$ ("HRA")-have caused employers to switch from HMOs to PPOs. Just as employers switched from traditional indemnity plans in the 1980 s and early 1990s, some scholars consider the move into CDHP as the first wave of consumerism in the twentyfirst century. ${ }^{63}$ CDHC appears to fix the problems left from HMOs: consumers under CDHCs are incentivized to be costsensitive and shop for high-value services, while not subjecting them to the financial risk of catastrophic illness. CDHCs allow consumers to be their own healthcare managers, which is designed to control costs and improve quality.

Out of this history of lowering costs and improving quality, the accountable care organization" (or "ACO") developed, a model that is attributed to Dr. Elliot Fisher, Director of the Center for Health Policy Research at Dartmouth Medical School. ${ }^{64}$ The concept of an ACO

60 The CDHP has a higher deductible, and the policy is based on either a HSA or a HRA, in which individuals set aside pretax dollars designated to cover routine care.

61 HSAs are tax-advantaged employee-owned savings accounts that may be used to pay for qualified medical expenses (HSAs must be paired with a high deductible health plan).

62 Health reimbursement accounts ("HRAs") are similar to HSAs, but they are owned and funded by employers and do not need to be coupled with a high-deductible plan (but often are).

63 Melinda B. Buntin et al., Consumer-Directed Health Care: Early Evidence About Effects On Cost And Quality, 25 HEALTH AFF. w516 (2006), http://content.healthaffairs.org/content/25/6/w516.full.pdf.

64 Kip Sullivan, The History and Definition of the "Accountable Care Organizations", Physicians For NAT'L HEALTH PRograM CAL. (Oct. 2010), http://pnhpcalifornia.org/2010/10/the-history-and-definitionof-the-"accountable-care-organization"/ Although the concept of accountable care had been around for quite some time, ACOs did not gain attention until 2006 and rapidly gained popularity with the publishing of a number of articles by Dr. Fisher and others. The buzz around ACOs reached its peak in 2009 with the term being used in all of the draft healthcare reform bills proposed by President Obama. Jenny Gold, Accountable Care Organizations, Explained, KAISER HEALTH NEWS \& NPR (Jan 18, 2011, 8:21 AM), http://www.kaiserhealthnews.org/Stories/2011/January/13/ACOaccountable-care-organization-FAQ.aspx. 
developed in response to the steadily increasing healthcare costs and the desire to improve Medicare and other private/public insurance programs. ${ }^{65}$

\section{Accountability to Patients for Cost Containment Under Affordable Care Act}

The Affordable Care Act included a Medicare Shared Savings Program, authorizing contracts with ACOs. ${ }^{66}$ ACOs are intended to coordinate patient care and improve clinical outcomes by linking providers who are accountable to the patients (and to each other) for achieving the goal of collaborative, efficient, cost-effective care. Shared savings will be available to providers if they meet certain criteria, including standards relating to quality, reporting, and governing structure. The ultimate goals of ACOs are to improve total cost, quality, and patient satisfaction. ${ }^{67}$ ACOs are designed to keep patients healthy and out of intensive care settings, while basing reimbursements on top performance goals that drive improved outcomes and cost effectiveness. ${ }^{68}$ ACOs also hold providers accountable to one another for outcomes and cost containment, and this topic is explored further in Part V below.

65 Fisher et al., supra note 31, 219-31.

66 Patient Protection and Affordable Care Act of 2010, Pub. L. No. $111-148, \S 3022,124$ Stat. 119-1025 (2010) (codified as amended at 42 U.S.C. $\S 1395 \mathrm{jjj}(2013))$.

67 See Jordan T. Cohen, $A$ Guide to Accountable Care Organizations, and Their Role in the Senate's Health Reform Bill, HEALTH REFORM WATCH (Mar. 11, 2010), http://www.healthreformwatch.com/2010/03/11/a-guide-to-accountablecare-organizations-and-their-role-in-the-senates-health-reform-bill/.

68 Jon Leibowitz, Chairman, Fed. Trade Comm'n, Remarks of FTC Chairman doe Leibowitz (As Prepared for Delivery), Antitrust in Healthcare Conference, Are Titanic Health Care Costs Sinking Us? What the FTC Is Doing to Keep Patients Afloat, FED. TRADE COMM'N 6-7 (May 3, 2012), www.ftc.gov/speeches/leibowitz/ 120503antitrusthealthcare.pdf 


\section{E. Toward Patient-Centered Medicine and Consumer- Driven Choices}

The transition from a physician-patient relationship where the physician is the center of the relationship, to a patient-centered approach where the patient is a consumer who has a number of choices and personal autonomy, has resulted in a number of other shifts. For example, "the relationship between patients and physicians was largely unmediated before the end of the twentieth century" 69 , but now patients have become consumers of healthcare services and health plans. ${ }^{70}$ The doctrine of informed consent recognizes the change in patient power as well..$^{71}$

Patients have also progressed to become clients of their caregivers and not merely wards or subjects. ${ }^{72}$ This subtle shift in the way patients are perceived offers an increase of power in the relationship because "medical care is a service, like any other, and ... patients are consumers who can

69 See Janet L. Dolgin, The Evolution of the "Patient": Shifts in Attitudes About Consent, Genetic Information, and Commercialization in Health Care, 34 HofsTrA L. REv. 137, 140, 175-79 (2005). See generally Mark A. Hall, The Legal and Historical Foundations of Patients as Medical Consumers, 96 GEO. L.J. 583, 587 (2008) (stating that healthcare initiatives "are meant to turn patients into consumers by placing them, rather than physicians, insurers, or the government, in the driver's seat for making medical spending decisions").

70 Michael J. Ramdass et al., Question of 'Patients' Versus 'Clients,' 21 J. QUALITY CLINICAL PRAC. 14, 14 (2001) (using the term "client" instead of "patient"); see generally Glen Cheng, The National Residency Exchange: A Proposal to Restore Primary Care in an Age of Microspecialization, 38 AM. J.L. \& MED. 158 (2012); Mark A. Hall, Rethinking Health Law: The History and Future of Health Care Law: An Essentialist View, 41 WAKE FOREST L. REV. 347, 359 (2006).

71 Orna Rabinovich-Einy, See You Out of Court? The Role of ADR in Health Care: Escaping the Shadow of Malpractice Law, 74 LAW \& CONTEMP. PROBS. 241, 247 n.19 (2011) ("In terms of patient rights, in the 1970 s, a series of court decisions made way for a new approach enshrining patients' right to make informed medical decisions and to view and correct their medical records, and delineated the care team's corresponding duties.")

72 See, e.g., Kristen Madison, Patients as "Regulators"?: Patients' Evolving Influence over Health Care Delivery, 31 J. LEGAL MED. 9, 1521 (2010); Dolgin, supra note 69, at 175-79. 
choose who should provide medical services and even what kind of services to purchase."73 In this way, patientcentered care:

suggests that patients' experiences as patients are important and should be taken into account, and that the law should recognize the vulnerability and suffering that illness can create and the dependency of the patient on others for knowledge, skill, or care. This in turn suggests that greater attention should be paid to the needs of the patient (beneficence) instead of merely the values of the patient (autonomy). ${ }^{74}$

With the increase of power, patients as consumers have expressed a desire to have more choices in terms of healthcare providers, insurance products, and election of procedures. ${ }^{75}$ And with more choices, patients become more accountable for their own care.

In connection with offering patients more choices, the Affordable Care Act emphasized the role of primary care and reduced reliance on specialty and emergency care. ${ }^{76}$

73 Marc A. Rodwin, Patient Accountability and Quality of Care: Lessons from Medical Consumerism and the Patients'Rights, Women's Health and Disability Rights Movements, 20 AM. J.L. \& MED. 147, 15357 (1994).

74 Lois Shepherd, Different Ways to Understand Patient-Centered Health Law, 45 WAKE FOREST L. REV. 1469, 1470 (2010).

75 See generally Troy J. Oechsner \& Magda Schaler-Haynes, Keeping it Simple: Health Plan Benefit Standardization and Regulatory Choice Under the Affordable Care Act, 74 ALB. L. REV. 241 (2011); Deborah Haas-Wilson, Arrow and the Information Market Failure in Health Care: The Changing Content and Sources of Health Care Information, 26 J. HEALTH, POL., POL'Y. \& LITIG. 1031, 1034 (2001) ("When no information on quality is available prior to purchase, quality deteriorates to the lowest level in the market - a serious market failure since mutually advantageous trades involving higher quality products do not take place.").

76 Karen Davis et al., How the Affordable Care Act Will Strengthen the Nation's Primary Care Foundation, 26 J. GEN. INTERNAL MED. 1201 (2011), available at http://www.ncbi.nlm.nih.gov/pmc/ articles/PMC3181291/pdf/11606_2011_Article_1720.pdf. 
The Affordable Care Act contains several important provisions in this regard, including availability for increased payments to primary care providers, incentives to develop modes of primary care delivery with medical homes, increased funding for primary care residency programs, opportunities for primary care providers to qualify for federal loans and loan forgiveness, and expanded coverage of preventive care services. ${ }^{77}$

\section{F. Patient-Centered Medical Home Model}

The Patient-Centered Medical Home ("Medical Home") is a care delivery model that has emerged as a method for addressing the various considerations discussed above. ${ }^{78}$ Developed in concept by the American Academy of Pediatrics, the Medical Home is broadly defined as primary care that is "accessible, continuous, comprehensive, familycentered, coordinated, compassionate, and culturally effective."79 Medical Homes offer patients greater input and choice and involve patients in the decisions about their own care. ${ }^{80}$ A Medical Home is designed to promote the coordination of patient care by a family physician, who is responsible for managing overall patient wellness. The patient's personal physician is familiar with the care for the patient and, along with the patient's family and a team of

77 See generally Cheng, supra note 70, at 158.

78 See Melinda K. Abrams et al., Can Patient-Centered Medical Homes Transform Health Care Delivery?, Commonwealth Fund (Mar. 27, 2009), http://www.commonwealthfund.org/Content/From-thePresident/2009/Can-Patient-Centered-Medical-Homes-TransformHealth-Care-Delivery.aspx; see also Daniel Fields et al., Driving Quality Gains and Cost Savings Through Adoption of Medical Homes, 29 HEALTH AFF. 819, 823-25 (2010), available at http://trinity.edu/ departments/healthcare/Content/FA10\%20McCaughrin\%20Articles/Fiel ds, \%20D..pdf.

79 See Abrams et al., supra note 78; Ad Hoc Task Force on Definition of the Medical Home, AM. ACAD. OF PEDIATRICS, The Medical Home, 90 PEDIATRICS 774 (1992), available at http://pediatrics.aappublications.org/content/90/5/774.full.pdf.

80 See generally Lawrence G. Smith \& Megan Anderson, New Directions in American Health Care, 39 HofstRA L. REv. 23 (2010). 
practitioners, works to coordinate access and referrals across medical specialties, hospitals, and nursing homes.

The Affordable Care Act includes grants to encourage specialists to provide support services for primary care providers operating within Medical Homes. ${ }^{81}$ The grants available under the Affordable Care Act are designed to provide support for Medical Homes that deliver preventive care services, assist in managing chronic diseases, and promote the development of patient care plans in collaboration with specialists and primary care physicians. ${ }^{82}$ The primary care providers are expected to meet regularly with the care team, provide a plan of coordinated care for each patient, and provide access to the patient's records as necessary for coordinated treatment. ${ }^{83}$

\section{G. Patient-Centered Outcomes Research Institute}

The Affordable Care Act established a new, nonprofit corporation, known as the Patient-Centered Outcomes Research Institute (the "Institute"), to conduct comparative effectiveness research on medical interventions. ${ }^{84}$ The purpose of the Institute is to assist patients to make informed healthcare decisions in collaboration with clinicians, purchasers, and policy-makers. The Institute was established to further the quality and relevance of evidence concerning the manner in which diseases, disorders, and other health conditions can effectively and appropriately be prevented, diagnosed, treated, monitored,

81 Patient Protection and Affordable Care Act of 2010, Pub. L. No. 111-148, § 3502(a), 124 Stat. 119-1025 (2010) (codified as amended at 42 U.S.C. § 256a-1 (2013)); see generally Stephen Zuckerman et al., Incremental Cost Estimates for the Patient-Centered Medical Home, 1325 COMMONWEALTH FUND $7-10$ (2009), http://www.commonwealthfund.org/ /media/Files/Publications/Fund\%20 Report/2009/Oct/1325_Zuckerman_Incremental_Cost_1019.pdf.

82 Patient Protection and Affordable Care Act of $2010 \S 3502(\mathrm{c})$ (codified as amended at 42 U.S.C. $\S 256 \mathrm{a}-1$ (2013)).

$83 I d . \S 3502(\mathrm{~d})(1)-(3)$ (codified as amended at 42 U.S.C. $\S 256 \mathrm{a}^{-1}$ (2013)).

$84 I d . \S 6301$ (codified as amended at 42 U.S.C. $\S 1420 \mathrm{e}(2013)$ ). 
and managed through research that considers variations in patient subpopulations. ${ }^{85}$

Congress intended for the comparative effectiveness research initiative to develop hard information about the comparative effectiveness of different medical products and services. This initiative is one of a long line of federal initiatives to address the rising costs of healthcare, as well as obtain better value for healthcare expenditures. The key question is whether the governance and design features of the institute that PPACA created to oversee the initiative will enable it to succeed where other federal efforts have faltered. ${ }^{86}$

This research is designed for patient-centered outcomes and helps people and their caregivers communicate and make informed healthcare decisions, allowing their voices to be heard in assessing the value of healthcare options. ${ }^{87}$ The structure of the Institute is unique as a private, non-profit entity governed by a board of directors appointed by the Comptroller General. The statute specifically provides that the Institute is "neither an agency nor establishment of the United States Government" and is organized under the District of Columbia Nonprofit Corporation Act. 88

\section{H. Promoting Accountability in Personal Healthcare Decisions}

Notwithstanding any of the other changes to the nation's healthcare system under the Affordable Care Act,

$85 \quad I d . \S 6301(\mathrm{~d})$ (codified as amended at 42 U.S.C. $\S 1420 \mathrm{e}(2013)$ ).

86 Eleanor D. Kinney, Comparative Effectiveness Research Under the Patient Protection and Affordable Care Act: Can New Bottles Accommodate Old Wine?, 37 AM. J.L. \& MED. 522, 524 (2011).

87 See Patient-Centered Outcomes Research, PATIENT-CENTERED OUTCOMES RES. INST., http://www.pcori.org/research-we-support/pcor/ (last updated Nov. 7, 2013).

$88 I d$. 
individual responsibility remains a key to success. An individual's willingness and ability to follow through on annual physicals, participate in preventative wellness activities including appropriate screenings, and following physician-recommended treatments are essential to reduce healthcare costs and improve the nation's overall health. ${ }^{89}$ Consider this in light of the fact that $75 \%$ of all healthcare costs can be attributed to chronic; preventable conditions and diseases that are significantly affected by lifestyle choices such as tobacco use, alcohol abuse, poor eating habits, and physical inactivity. ${ }^{90}$

In the context of determining how to hold a patient accountable for care, many other considerations must be confronted and addressed. For example, are all patients equally accountable, or are some patients held to a different standard because of their respective personal, social, economic, or other factors? What about patients. who genuinely cannot understand the healthcare instructions of their providers? ${ }^{91}$ Also, how does the system address those populations that historically have experienced higher rates of healthcare problems than others?

For example, studies show that "racial and ethnic minorities tend to experience disproportionately high rates of mortality, chronic and debilitating illnesses, and infectious diseases, and they are less likely to receive certain kinds of diagnostic testing, medical procedures, and medication than non-minorities."92 And, "[t]he strange

89 See generally Smith \& Anderson, supra note 80, at 23.

90 DeP'T Health \& Human Servs., PREvention MaKes Common “CENTS" 1 (2003), http://aspe.hhs.gov/health/prevention/prevention.pdf.

91 Brietta Clark, Using Law to Fight a Silent Epidemic: The Role of Health Literacy in Health Care Access, Quality, \& Cost, 20 ANNALS HEALTH L. 253, 306 (2011) ("While it is certainly unfair to punish a physician for a bad result brought about by a patient's disregard of the physician's instructions, it seems equally troubling to hold patients accountable for information that is often not communicated in a clear or understandable way. To what extent can or should health literacy be relevant in helping courts make this distinction?").

92 INST. MED., UNEQUAL TREATMENT: CONFRONTING RACIAL AND ETHNIC Disparities IN HEALTh CARE 2-3 (Brian D. Smedley et al., eds. 2003), available at http://books.nap.edu/openbook.php?record_id=10260; see also Clark, supra note 91 , at 317 . 
history of race and class intersecting in U.S. medicine dates back to the antebellum period with medical experiments on enslaved women,"93 as well as "medical experimentation on vulnerable and often uninformed patients, including illiterate men, children, and prisoners." 94

Preventative care is a means by which patients are responsible for proactively addressing potential health concerns before they are able to become major issues. Given the various considerations with respect to accountability of individual health decisions, the Affordable Care Act provides generally for the creation of a National Prevention, Health Promotion, and Public Health Council (the "Council") to coordinate federal agencies and initiatives for preventative wellness and public health. ${ }^{95}$ The Council is headed by the Surgeon General and is responsible for submitting an annual report to the President and to Congress containing "a list of national priorities on health promotion and disease prevention to address lifestyle behavior modification (smoking cessation, proper nutrition, appropriate exercise, mental health, behavioral health, substance use disorder, and domestic violence screenings) and the prevention measures for the 5 leading disease killers in the United States."96

The Affordable Care Act encourages preventative wellness by mandating that insurance companies offer a free annual wellness visit and complete coverage, without coinsurance, of services recommended in an insured's "personalized prevention plan" created by his or her

93 Michele Goodwin \& L. Song Richardson, Patient Negligence, 72 L. \& CONTEMP. PROBS. 223, 230 (2009).

$94 \quad I d$.

95 Patient Protection and Affordable Care Act of 2010, Pub. L. No. 111-148, § 4001, 124 Stat. 119-1025 (2010) (codified as amended at 42 U.S.C. $\S 300 \mathrm{u}-10(2013))$.

96 Id.; see generally NAT'L PREVENTION, HEALTH PROMOTION AND Pub. Health Council, National Prevention Strategy: America's PLAN FOR BETTER HEALTH AND WELlNESS (2011), available at http://www.surgeongeneral.gov/initiatives/prevention/strategy/report.pd f. 
primary care provider. ${ }^{97}$ In addition, many preventive services now are required to waive any coinsurance payments that were previously required. ${ }^{98}$ For example, the Affordable Care Act requires health insurers to cover $100 \%$ of the costs of immunizations, pediatric preventive care services, and Grade A or B preventive services recommended by the United States Preventive Services Task Force without imposing any cost-sharing obligations on their insured. ${ }^{99}$

The goal of patient accountability is twofold: holding providers accountable for the health outcomes (and costs) of patients and holding patients accountable for their own care. ${ }^{100}$ As the perception of the physician-patient relationship shifts, and as patients become more involved in their own health through preventative care and lifestyle choices, providers will also be expected to be accountable to populations of patients for health outcomes. Together, this mutual accountability is expected to create a systemic change.

\section{COMMUNITY ACCOUNTABILITY}

The Affordable Care Act is designed to promote community accountability. Indeed, several methods for impacting care delivery in communities are part of the Affordable Care Act. For example, Community Health Centers are being funded to offer community infrastructure with the goal of addressing local healthcare needs, particularly for the poor and underserved. Programs for reducing hospital readmissions and assisting in transitioning patients from an acute care provider to a postacute care provider are expected to aid in a patient's transition from hospital to community. Also, exempt

97 Patient Protection and Affordable Care Act of $2010 \S 4103(\mathrm{a})$ (codified as amended at 42 U.S.C. $\S 1395 \times$ (2013)).

$98 \quad I d . \S 10406$ (codified as amended at 42 U.S.C. $\S 13951(2013)$ ).

99 Id.

100 See generally, Julie A. Muroff, Policing Willpower: Obesity as a Test Case for State Empowerment of Integrated Health Care, 11 Hous. J. HEALTH L. \& POL'Y 47 (2011). 
hospitals are now held accountable to monitor local health needs and report their activities to address these needs, or face financial penalties.

At the heart of the notion of community accountability are more fundamental considerations: how can individuals and organizations be held accountable to their communities? Does the standard of accountability include the entire community, or should access to care be available only to those who can afford it? What burden should insurance companies, healthcare providers, and employers carry with regard to the community's health? What about caring for underserved populations? And perhaps most controversially, what role does the government have in filling in the natural gaps that have arisen as a result of the way healthcare has been delivered, financed and utilized over recent decades in the United States?

Some would argue that the role of serving the needs of healthcare in communities should be upon a variety of sources rather than the federal government, including for example, individuals, non-profit organizations, hospitals, and emergency rooms. ${ }^{101}$ Others would prefer that the federal government take a more aggressive role in regulating these areas. ${ }^{102}$ Regardless of ideology, however,

101 See, e.g., Paul Ryan, Costs, Ethics \& The Law: Essay: Health Care Reform: The Way Forward, 25 Notre Dame J. L. EThics \& PuB. POL'Y 337, 340 (2011) (discussing the government's growing role in health care and arguing against the Affordable Care Act); Elizabeth Weeks Leonard, New Directions in American Health Care: Innovations from Home and Abroad, Article: Rhetorical Federalism: The Value of State-Based Dissent to Federal Health Reform, 39 HoFsTRA L. REV. 111 (2010) (arguing for the repeal of the Affordable Care Act); Michael D. Tanner, Commentary: Universal Health Care Not Best Option, Cato INST. (Feb. 23, 2009), http://www.cato.org/publications/commentary/ universal-health-care-not-best-option (reviewing the high cost of universal health care).

102 See, e.g., Len M. Nichols, Making Health Markets Work Better Through Targeted Doses of Competition, Regulation, and Collaboration, 5 ST. LOUIS U. J. HEALTH L. \& POL'Y 7 (2011) (arguing the benefits of "structured competition" and collaboration in health care reform); Julie E. Kass \& John S. Linehan, Note, Fostering Healthcare Reform Through a Bifurcated Model of Fraud and Abuse Regulation, $5 \mathrm{~J}$. 
the role of the community in the provision, delivery and receipt of care is at the heart of the solution on both ends of the spectrum because most experts agree that home-based and community-based care can lead to better health outcomes. ${ }^{103}$ The Affordable Care Act is designed to generate such accountability, with the hope that a dramatic shift in the way care is delivered will occur, that the quality of care improves and that the overall cost of care will decrease. ${ }^{104}$

\section{A. Community Health Centers}

The Affordable Care Act identified Federally-Qualified Health Centers, also known as "Community Health Centers" as a primary way to impact local communities. ${ }^{105}$ Although Community Health Centers ("CHC") have been

HEALTH \& LIFE SCI. L. 75 (2012) (arguing for the government's increased regulatory role in limiting fraud and abuse for health care costs).

103 See, e.g., Home - The Best Place for Health Care, A Positioning Statement from The Joint Commission on the State of the Home Care Industry, JOINT COMM'N (Oct. 18, 2011), http://www.jointcommission.org/assets/1/18/Home_Care_position_paper_ 4_5_11.pdf ("Just about everyone agrees: the home is the best setting for providing health care to increasing numbers of patients"); Best Care at Lower Cost, The Path to Continuously Learning Health Care in America, Recommendations, INST. MED. (Sept. 2012), http://www.iom.edu/ /media/Files/Report\%20Files/2012/Best-Care/

Best\%20Care\%20at\%20Lower\%20Cost_Recs.pdf (including a recommendation about the importance of community accountability).

104 Aligning Forces for Quality, Improving Health \& Health Care in Communities Across America, RoBERT WoOD JOHnson Found. (May 2011), http://forces4quality.org/sites/default/files/

AF4Q_BROCHUREm4WEB_May2011.pdf; Pamela Mitchell et al., Core Principles \& Values of Effective Team-Based Health Care, INST. MED. NAT'L ACADS. (Oct. 2012), https://www.nationalahec.org/pdfs/VSRTTeam-Based-Care-Principles-Values.pdf.

105 Public Health Service Act, Pub. L. No. 78-410, § 330, 58 Stat. 682 (1944) (codified as amended at 42 U.S.C. $§ ~ 254 \mathrm{~b}$ (2013)), amended by Patient Protection and Affordable Care Act of 2010, Pub. L. No. 111148, § 10406, 124 Stat. 119-1025 (2010) (codified as amended at 42 U.S.C. $\S 254 \mathrm{~b}-2$ (2013)), amended by Healthcare and Education Reconciliation Act, Pub. L. 111-152, 124 Stat. 1029-84 (2010). 
part of community care delivery since 1965,106 the Affordable Care Act made a deliberate economic investment in the growth and expansion of these facilities. ${ }^{107}$ As part of this effort, the Affordable Care Act established funding to provide $\$ 11$ billion over a five-year period for the operation, expansion, and construction of Community Health Centers nationwide. ${ }^{108}$ The purpose of the funding is to prepare Community Health Centers for what is expected to be an increase in patients who are seeking care with their new insurance coverage. ${ }^{109}$

106 Kathleen Sebelius, Op-Ed, ACA Gets Care To Those In Most Need, AlbUQUERQUE J. (Sept. 19, 2012), http://www.hhs.gov/secretary/about/opeds/aca_care_to_those.html

("First established in 1965, today there are more than 8,500 community health center sites across the country. ..."); Roger Wilson, Community Health Centers: Optometric Care within the Public Health Community, OLD PosT PUB. (2009), available at http://webpages.charter.net/ oldpostpublishing/oldpostpublishing/Section \%203,\%20Governmental\%2 0Role\%20in\%20Health\%20Care/Sect\%203,\%20Community\%20Health\% 20Centers\%20by\%20Wilson.pdf (describing history and impact of Community Health Centers); Sara Rosenbaum et al., Community Health Centers in an Era of Health System Reform and Economic Downturn: Prospects and Challenges, HENRY J. KAISER FAM. FOUND. 2 (Mar. 2009), http://www.kff.org/uninsured/upload/7876.pdf ("In 2007, more than 1,200 health center grantees working in nearly 7,200 delivery sites throughout the nation furnished care to more than 16 million patients.").

107 Carolyn McClanahan, Community Health Centers -- Providing A Base Of Care, ForBes (July 16, 2012, 10:08 AM), http://www.forbes.com/sites/carolynmcclanahan/2012/07/16/communityhealth-centers-providing-a-base-of-care/ (describing Community Health Centers as "hope for the newly insured").

108 Health ReS. AND SERvs. AdMin., DEP'T HEalth aND HumaN Servis., The AfFordable CARE ACT AND Health Centers, http://bphc.hrsa.gov/about/healthcenterfactsheet.pdf; Health Reform FAQs for Health Centers, NAT'L ASS'N CMTY. OF HEALTH CTRS., http://www.nachc.com/client/Health\%20Reform\%20FAQs\%20-

Final\%20for\%20Web.pdf.

109 Expanding Health Centers Under Health Reform: Doubling Patient Capacity and Bringing Down Costs, NAT'L Ass'N CMTY. HEALTH CTRS. (June 2010), http://www.nachc.com/client/

HCR_New_Patients_Final.pdf [hereinafter NAT'L Ass'N CMTY. HEALTH CTRS., Expanding Health Centers]; Leighton Ku et al., Policy Brief No. 19: Using Primary Care to Bend the Curve: The Effect of National 
Funding of Community Health Centers is not solely a product of the Affordable Care Act or of Democratic politics. Indeed, President George W. Bush doubled financing for these organizations during his presidency. 110 The increased focus on, and patient visits to Community Health Centers is undisputed and dramatic. ${ }^{111}$ The Obama administration also has targeted Community Health Centers as a way to emphasize primary and preventive services in a model with unique characteristics. ${ }^{112}$ For example, these organizations serve populations and communities with primary healthcare services, offering sliding fee scales based on patients' ability to pay.113 The target population for Community Health Centers is those individuals located in rural areas, as well as the poor and underserved populations. ${ }^{114}$ Sometimes, logistical issues such as cultural difference or language barriers can limit the overall

Health Reform on Health Center Expansions, GEIGER GIBSON / RCHN CMTY. HEAlth Found. RES. Collaborative (June 30, 2010).

110 Kevin Sack, Community Health Clinics Increased During Bush Years, N.Y. TimES (Dec. 26, 2008), http://www.nytimes.com/2008/12/26/ world/americas/26iht-bush.1.18936658.html?_r=0 ("As governor of Texas, Bush came to admire the missionary zeal and cost-efficiency of the not-for-profit community health centers, which qualify for federal operating grants by being located in designated underserved areas and treating patients regardless of their ability to pay. He pledged support for the program while campaigning for president in 2000 on a platform of "compassionate conservatism.").

111 Irwin Redlener \& Roy Grant, America's Safety Net and Health Care Reform-What Lies Ahead?, 361 NEw. EnGLAND J. MED. 2201, 2203 (2009) (stating that during the time period between "June 2008 and June 2009, visits to community health centers increased by $14 \%$, and visits by uninsured patients by $21 \%$ ").

112 The Obama Administration and Community Health Centers, WHITEHOUSE.GOV, http://www.whitehouse.gov/sites/default/files/05-0112_community_health_center_report.pdf.

113 Sara Rosenbaum et al., Community Health Centers in an Era of Health System Reform and Economic Downturn: Prospects and Challenges, HENRY J. KAISER FAM. Found. 2 (Mar. 1, 2009), http://www.kff.org/uninsured/upload/7876.pdf.

114 Id.; see generally NACHC Principles for National Health Reform, NAT'L ASS'N CMTY. HEALTH CTRS., http://www.nachc.com/client/ NACHC\%20Principles\%20for\%20National\%20Health\%20Reform.pdf. 
effectiveness of care. ${ }^{115}$ However, the goal of a Community Health Center is to provide a continuum of care approach that includes physicians, nurse practitioners, physician assistants, nurses, dental providers, midwives, behavioral healthcare providers, social workers, health educators, and many others. ${ }^{116}$

One of the expected shifts in the way care is delivered is a decrease in the number of charity care patients at hospitals and emergency rooms and an increase in the number of previously uninsured who will be able to access medical care through Community Health Centers, which will now be able to get reimbursed for their expenditures rather than exist solely on meager fundraising efforts and small government grants. ${ }^{117}$ Under the Affordable Care Act, the estimated capacity in Community Health Centers is expected to "increase considerably, helping to meet the new

115 See generally Efrat Shadmi, Quality of Hospital to Community Care Transitions: the Experience of Minority Patients, 25 INT'L J. QUALITY HEALTH CARE 255 (2013), http://intqhc.oxfordjournals.org/ content/early/2013/04/08/intqhc.mzt031.abstract (last visited Dec. 28, 2013); Paul M. Schyve, Language Differences as a Barrier to Quality and Safety in Health Care: The Joint Commission Perspective, $22 \mathrm{~J}$. GEN. INTERNAL MED. 360, 360-61 (2007), available at http://www.ncbi.nlm.nih.gov/pmc/articles/PMC2078554/pdf/11606_2007_ Article_365.pdf.

116 See, e.g., Kathy Poppitt \& Sheryl Tatar Dacso, Federally Qualified Health Centers: $A$ Healthcare Delivery Model for a Newly Reformed Health System, 23 HEALTH LAW. 1, 3 (2010).

117 Rick Cohen, Community Health Centers Respond to Impending $A C A$ Changes, NonPRofit Q. (Apr. 8, 2013, 2:25 PM), http://www.nonprofitquarterly.org/policysocial-context/22098-

community-health-centers-respond-to-impending-aca-changes.html; Andrea Kovach \& Rachel Gielau, The Great Medicaid Expansion of 2014 What it Is and How to Make it Succeed, 45 ClEARINGHOUSE REV. 388, 395 (2012) ("Community health care providers will be vital to effective outreach because, even when adults are uninsured, they are likely to seek care at a community health center, hospital emergency room, or drug treatment center. Other avenues for outreach are unemployment offices, job-training centers or career fairs, community colleges, food stamp offices, the Social Security Administration's Supplemental Security Income offices, charity care organizations such as food banks and domestic violence shelters, and local businesses."). 
demands for primary health care that are expected once more people have health insurance coverage."118

A predictable response to the increased funding of Community Health Centers follows: "This sounds great! But what is it going to cost? And who is going to pay for it?"

According to the National Association of Community Health Centers, "research studies demonstrate that health centers yield substantial cost savings to the health care system by reducing emergency department visits, hospitalizations, and other avoidable, costly care."119 The study relied upon by the National Association of Community Health Centers suggests that the increased funding of Community Health Centers will actually result in long-term savings to the federal healthcare program and offer ways to address the increased demand for healthcare under the Affordable Care Act:

Our findings indicate that the expansion of community health centers will play an essential role in addressing two of the longterm challenges of health reform: curbing the growth of overall health care expenditures and bolstering the capacity of the primary care system to meet the needs of the millions of newly insured Americans. ${ }^{120}$

Indeed, this study further concludes that the role of Community Health Centers is so crucial to effectively managing healthcare costs for populations, that "the expansion of health centers can reduce both federal and state Medicaid expenditures."121 The expansion of Community Health Centers will also result in the creation

$118 \mathrm{Ku}$ et al., supra note 109 , at 6 .

119 See NAT'L ASS'N CMTY. Health CTRS., Expanding Health Centers, supra note 109; see generally $\mathrm{Ku}$ et al., supra note 109.

$120 \mathrm{Ku}$ et al., supra note 109 , at 9.

121 Id. 
of jobs for providers and other workforce at these facilities. ${ }^{122}$

While opposition remains to the increased emphasis in Community Health Centers, ${ }^{123}$ the Affordable Care Act has targeted these organizations as a fundamental way that care will be delivered in the twenty-first century. By focusing on local entities that provide care to the poor and underserved, the Affordable Care Act is intentionally requiring community accountability.

\section{B. Transitioning Patients from Hospitals Back to the Community}

Another problem facing communities is the difficult transition for inpatients from hospital care to another stage of post-acute care. When a patient is transferred from one healthcare provider to another, the likelihood for readmission or need for additional inpatient care remains a costly scenario for many patients and providers. ${ }^{124}$ Studies suggest that between $18-20 \%$ of Medicare patients who are admitted to acute care hospitals are later readmitted within thirty days of discharge, at an estimated annual cost of as

122 See Community Health Centers Lead the Primary Care Revolution, NAT'L ASS'N CMTY. HEALTH CTRS. (Aug. 2010), http://www.nachc.com/client/documents/Primary_Care_Revolution_Fina 1_8_16.pdf.

123 See generally Dan Hawkins \& DaShawn Groves, The Future Role of Community Health Centers in a Changing Health Care Landscape, 34 J. AMBULATORY CARE MANAGE 91 (2011) (describing "often-powerful political opposition"); BONNIE LEFKOWITZ, COMMUNITY

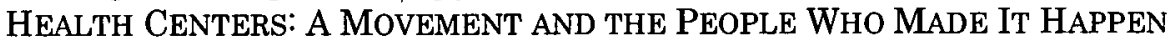
12 (2007).

124 Marciarillet, supra note 43, at 44 ("It turns out that Medicare hospitalization recidivism is not one problem but a constellation of interlocking problems: primarily those of the failure to provide ongoing care for the chronically ill, the problem of medically inappropriate primary hospitalizations and rehospitalizations, and the failure to effectively plan and deliver the services necessary for successful community re-entry upon acute care hospital discharge. Combine these with our systemic problems of failure to deliver primary care and the standardless provision of health care and the recipe is complete."). 
much as $\$ 26$ billion. ${ }^{125}$ Worse, within ninety days of discharge, the readmission percentage rises to $34 \% .{ }^{126}$ This means that statistically, one out of every three patients who are transitioned out of a hospital will be back again within three months, and this is a considerable concern and financial burden for communities. Accountability for transitioning care in a way that reduces readmissions is a responsibility facing a number of participants in the process. ${ }^{127}$

The Affordable Care Act attempts to address the frequency of readmission in several ways. For example, the Affordable Care Act created a new Center for Medicare and Medicaid Innovation that will be tasked with identifying local models that address a defined population with poor clinical outcomes or avoidable expenditures, and then expanding solutions nationwide. ${ }^{128}$ The Affordable Care Act also funded research for, among other things, practical methods for reducing preventable hospital admissions and readmissions. ${ }^{129}$ The Affordable Care Act also established a National Pilot Program on Bundling beginning in 2013, which establishes a national, voluntary five-year pilot program on bundling payments to providers around ten conditions. ${ }^{130}$

125 See Stephen F. Jencks et al., Rehospitalizations Among Patients in the Medicare Fee-for-Service Program, 360 NEW ENG. J. MED. 1418, 1421 (2009), available at http://www.nejm.org/doi/pdf/10.1056/

NEJMsa0803563; see also Laura Landro, Keeping Patients from Landing Back in Hospital, WALL ST. J. (Dec. 12, 2007, 12:01 AM), http://online.wsj.com/article/SB119741713239122065.html; see also Marciarillet, supra note 43 , at 44-45, 80, n.17.

126 Jencks et al., supra note 125 , at 1421 .

127 Douglas McCarthy et al., Recasting Readmissions by Placing the Hospital Role in Community Context, 309 JAMA 351 (2013).

128 Patient Protection and Affordable Care Act of 2010, Pub. L. No. $111-148, \S 3021,124$ Stat. 119-1025 (2010) (codified as amended at 42 U.S.C. $\S 300 \mathrm{jj}-51(2013))$.

129 Id. $\S 3501$ (codified as amended at 42 U.S.C. $\S 299 \mathrm{~b}-33$ (2013)).

130 Id. $\S 3023$ (codified as amended at 42 U.S.C. $\S 1395 c c-4$ (2013)). The Secretary of the Department of Health and Human Services selects the ten conditions to be included in the pilot program based upon a combination of chronic and acute conditions, surgical, and medical conditions, and conditions where providers are able to improve quality 
The Affordable Care Act established the Hospital Readmissions Reduction Program, which is designed to offer hospitals a financial disincentive for readmissions. ${ }^{131}$ Beginning in 2013, hospitals that have higher than expected readmissions based on the thirty-day readmission measures for heart attack, heart failure, and pneumonia will have their Medicare reimbursement decreased for all Medicare discharged patients. ${ }^{132}$ As a way to assist hospitals with high readmission rates, the Affordable Care Act also implemented programs for Patient Safety Organizations to assist hospitals in the reduction of these readmissions. ${ }^{133}$

These programs are focused upon hospitals' efforts to address the care transition problem, because hospitals are able to focus on those components that they are directly responsible for, including the quality of care during the hospitalization and their role in the patient discharge process. However, there are multiple factors along the care continuum that impact readmissions, and focusing accountability on the actions of post-acute care providers, as well as the patients themselves are also important parts of the equation. Hospitals are not the sole cause of readmissions because "[c]ertain conditions at discharge are disproportionately represented in unplanned Medicare rehospitalizations."134

while reducing costs, that are able to be bundled across a spectrum of care.

131 Id. $\S 3025$ (codified as amended at 42 U.S.C. $\S 1395 w w(2013)$ ).

132 See Corrections to Final Rules Relating to Medicare, Hospitals, and Other Healthcare Providers, 78 Fed. Reg. 15,822 (Mar. 13, 2013) (codified at scattered parts of 42 C.F.R.); see also Readmissions Reduction Program, CTR. FOR MEDICARE \& MEDICAID SERVS. http://www.cms.gov/Medicare/Medicare-Fee-for-Service-Payment/ AcuteInpatientPPS/Readmissions-Reduction-Program.html (last visited Dec. 28, 2013).

133 Patient Protection and Affordable Care Act of $2010 \S 399 \mathrm{kk}$ (codified as amended at 42 U.S.C. $§ 280 \mathrm{j}-3$ (2013)).

134 Marciarillet, supra note 43 , at $46-47$ ("The top five medical conditions generating the most readmissions concern: heart failure, pneumonia, chronic obstructive pulmonary disease, psychoses, and gastrointestinal problems."). 
Recognizing the varying roles of hospitals, patients, and post-acute care providers in the transition process, the Affordable Care Act also established a Community-Based Care Transitions Program ("CCTP") 135 for improving care transitions from the hospital to other settings and reducing readmissions for high-risk Medicare beneficiaries. The CCTP is particularly notable in its design as a deliberate way for hospitals and community organizations to become accountable to one another. The CCTP is also part of a public-private partnership, Partnership for Patients, ${ }^{136}$ offering yet another program for encouraging community accountability to improve quality, reduce cost, and improve patient experience.

The CCTP, launched in 2011, will run for five years with up to $\$ 500$ million in funding available. ${ }^{137}$ The goals of the CCTP are to improve transitions from the inpatient hospital setting to other care settings to improve quality of care, to reduce readmissions for high risk beneficiaries, and to document measurable savings to the Medicare program. ${ }^{138}$ The CCTP proposes to coordinate the efforts of local, community-based organizations ("CBOs") to manage Medicare patients' transitions out of hospitals and into the community. ${ }^{139}$

Collectively, these efforts attempt to provide ways in which individuals and organizations can held accountable to their communities. The Affordable Care Act's emphasis on community accountability focuses specifically on ways that the poor and underserved are able to access care.

135 CCTP was created by Patient Protection and Affordable Care Act of $2010 \S 3026$ (codified as amended at 42 U.S.C. $\$ 1395 \mathrm{~b}-1$ (2013)).

136 See Partnership for Patients, CTRS. FOR MEdICARE \& MEDICAID SERVS., http://innovation.cms.gov/initiatives/Partnership-for-Patients/ index.html (last visited Dec. 28, 2013).

137 Community-Based Care Transitions Program, CTRS. FOR MEDICARE AND MEDICAID SERVS., http://innovation.cms.gov/initiatives/ CCTP/ (last visited Dec. 28, 2013).

138 Id.

139 Id 


\section{Accountability of Exempt Hospitals to Their Communities}

The Affordable Care Act also addressed a growing concern that tax-exempt hospitals are not held accountable to their communities. ${ }^{140}$ The concern derives from the perception that some non-profit hospitals operate and make decisions like any for-profit business and yet receive a significant tax break in their operations. ${ }^{141}$ For the past several years, 501(c)(3) hospitals have been at the focus of Senate Finance Committee's Charles Grassley's call for accountability. ${ }^{142}$ Senator Grassley, a Republican, identified a need for exempt hospitals to show that they deserve their exemption. ${ }^{143}$ In a similar type of accountability dispute, Provena Covenant Medical Center

140 Thomas Lee Hazen \& Lisa Love Hazen, Punctilios and Nonprofit Corporate Governance - A Comprehensive Look at Nonprofit Directors' Fiduciary Duties, 14 U. PA. J. Bus. L. 347, 353 (2012) ("A specific example of the debate surrounding the federal tax exemption is the concern in recent years that nonprofit hospitals are really disguised for-profit enterprises with an undeserved tax advantage."); see also Scott Allen \& Marcella Bombardieri, Much is Given by Hospitals, More is Asked; Nonprofits Reaping More in Tax Breaks than They Report in Charity Work. Some Say That Must Change, Bos. GLOBE, May 31, 2009, at 1; Lynnore Seaton \& Beth C. Koob, Tax-Exempt Hospitals and Community Benefit, HEALTH LAW., June 2009, at 37, 38 (stating that there is "no clear guidance in the law as to what Congress considered to be charitable, or what the motivations were for exempting charitable organizations from taxation.").

141 Lynnore Seaton \& Beth C. Koob, supra note 140, at 38.

142 Memorandum from the U.S. Committee on Finance to Reporters and Editors, Grassley: GAO Finds Troubling Nonprofit Hospitals' Executive Compensations (July 28, 2006), available at http://www.finance.senate.gov/newsroom/chairman/release/?id=b43c8ad 4-5201-410c-860d-b63ab8ec92d3 (last visited Dec. 28, 2013); see also Lisa Kinney Helvin, Note, Caring for the Uninsured: Are Not-for-Profit Hospitals Doing Their Share?, 8 YALE J. HEALTH POL'Y L. \& ETHICS 421, 449 (detailing Senator Grassley's various inquiries into hospital exemption).

143 Press Release, Senator Chuck Grassley, Grassley's Provisions for Tax-exempt Hospital Accountability Included in New Health Care Law (Mar. 24, 2010), available at http://www.grassley.senate.gov/news/ Article.cfm?customel_dataPageID_1502 $=25912$ (last visited Dec. 28, 2013). 
lost its state property tax exemption because it did not demonstrate that it offered a substantial amount of medical services to the poor. ${ }^{144}$

Nationwide, about 2900 hospitals (60\% of hospitals) are non-profit, and the value of tax-exemption collectively for these hospitals is more than $\$ 12.6$ billion. ${ }^{145}$ In response, communities expect accountability from their local nonprofit hospitals in the form of services in addition to traditional fee-for-service medical care. For example these services may include providing, below-cost medical services for the poor, the availability of emergency room services and other medical services, access to free clinics and preventative care, education of the public on medical matters, and involvement and financial support of local charities. ${ }^{146}$

Exempt hospitals are "organized and operated exclusively for ... charitable . . . purposes"147 and receive the benefit of their exempt status in part based upon the perceived "community benefit" that they provide to their localities. ${ }^{148}$ Prior to the Affordable Care Act and beginning with the 2009 tax year, the Internal Revenue Service ("IRS") introduced a revised Form 990, which sets up a

144 Provena Covenant Med. Ctr. v. Dep't of Revenue, 925 N.E.2d 1131, 1144 (Ill. 2010).

145 Nonprofit Hospitals and the Provision of Community Benefits, CONG. BUDGET OFFICE 3, 5 (2006), available at http://www.cbo.gov/sites/ default/files/cbofiles/ftpdocs/76xx/doc7695/12-06-nonprofit.pdf; see also What's New with Community Benefit? ROBERT WoOD JOHNSON FOUND. (Oct. 2012), http://www.rwjf.org/content/dam/farm/reports/issue_briefs/ 2012/rwjf402124.

146 Jim Doyle, Nonprofit Hospitals' Huge Tax Breaks Under Increasing Scrutiny, ST. LouIS PosT-DisPATCH (Oct. 23, 2011, 11:00 PM), http://www.stltoday.com/business/local/article4a0dcd17-40b3-589fb0e7-c3dc14b62804.html.

147 Exemption from Tax on Corporations, Certain Trusts, Etc., 26 U.S.C. § 501(c)(3) (2013).

148 Rev. Rul. 69-545, 1969-2 C.B. 117, available at http://www.irs.gov/pub/irs-tege/rr69-545.pdf; see generally INTERNAL REVENUE SERV., IRS EXEMPT ORGANIZATIONS (TE/GE) HOSPITAL COMPLIANCE PROJECT FINAL REPORT (2009), available at http://www.irs.gov/pub/irs-tege/frepthospproj.pdf. 
required and standardized method for all nonprofit hospitals to report financial information. ${ }^{149}$

The Affordable Care Act includes specific public reporting obligations for hospitals to hold them accountable to their communities and to ensure that their exempt status is deserved. ${ }^{150}$ The Affordable Care Act creates a new $\S$ 501(r) of the Internal Revenue Code, ${ }^{151}$ detailing new requirements for hospitals, which include the following:

1. Conduct a "community health needs assessment" ("CHNA") at least once every three years and adopt a strategy to respond to the needs identified by the assessment;

2. Establish written financial assistance policies addressing patient eligibility for financial assistance and emergency care;

3. Limit the amount charged to patients eligible for financial assistance for emergency or medically necessary care to the amount generally billed for insured patients; and

4. Refrain from pursuing "extraordinary collection actions" without first inquiring whether a patient is eligible for financial assistance. 152

IRS published a proposed rule titled Community Health Needs Assessments for Charitable Hospitals, detailing reporting obligations for hospitals as part of the Affordable Care Act and clarifying the consequences for failing to meet these and other requirements for charitable hospital

149 Internal Revenue Serv., DeP'T Treasury, OMB No. 15450047, IRS FORM 990, RETURN OF ORGANIZATION EXEMPT FROM INCOME TAX (2012), available at http://www.irs.gov/pub/irs-pdf/f990.pdf.

150 Patient Protection and Affordable Care Act of 2010, Pub. L. No. 111-148, §9007, 124 Stat. 119-1025 (2010) (codified as amended at scattered sections of 26 U.S.C.).

151 Exemption from Tax on Corporations, Certain Trusts, Etc., 26 U.S.C. $\S 501(r)$ (2013).

152 Id.; Patient Protection and Affordable Care Act of $2010 \S 9007$ (codified as amended at scattered sections of 26 U.S.C.). 
organizations. ${ }^{153}$ At the heart of these new requirements for exempt hospitals is a standard of accountability that requires hospitals to demonstrate tangible, identifiable community benefits in exchange for their tax exemption. The CHNA requirement holds hospitals accountable, at least once every three years, for soliciting input from community representatives. ${ }^{154}$ Once Hospitals complete the CHNA, they must make the assessment "widely available to the public."155 Hospitals must adopt an implementation strategy to meet the community health needs identified in the health needs assessment must report to the Internal Revenue Service how the organization is addressing the needs identified. ${ }^{156}$

Hospitals must now adopt written financial assistance policies that establish clear criteria for how patients will receive financial assistance. The written financial assistance policy must include (i) eligibility criteria for financial assistance and whether such assistance includes free or discounted care, (ii) the basis for calculating amounts charged to patients, (iii) the method for applying for financial assistance, (iv) in the case of an organization which does not have a separate billing and collections policy, the actions the organization may take in the event of nonpayment, including collections action and reporting to credit agencies, and (v) measures to widely publicize the policy within the community to be served by the organization. 157 Hospitals must also refrain from engaging in extraordinary collection efforts before making reasonable efforts to determine whether the individual from whom

153 Community Health Needs Assessments for Charitable Hospitals, 78 Fed. Reg. 20,523 (proposed April 5, 2013) (to be codified at 26 C.F.R. pts. 1, 53).

154 Exemption from Tax on Corporations, Certain Trusts, Etc., 26 U.S.C. $\S 501(\mathrm{r})(3)(\mathrm{B})(\mathrm{i})$.

155 Exemption from Tax on Corporations, Certain Trusts, Etc., 26 U.S.C. $\$ 501(\mathrm{r})(3)(\mathrm{B})(\mathrm{ii})$.

156 Patient Protection and Affordable Care Act of $2010 \S 9007(d)$ (codified as amended at 26 U.S.C. $\$ 6033$ (2013)).

157 Patient Protection and Affordable Care Act of 2010 sec. 9007(a)(4), § 501(r)(4) (codified as amended at 26 U.S.C. $\S 501(\mathrm{r})(4)$ (2013)). 
collection is sought would be eligible for assistance under the financial assistance policy. ${ }^{158}$

Of all the community accountability standards established by the Affordable Care Act, the hospital requirements are perhaps the most comprehensive. A major goal of this provision is to hold hospitals accountable for addressing any disparities in healthcare that exist among populations. ${ }^{159}$ In response to years of questioning whether hospitals deserve their tax-exempt status, the Affordable Care Act requires tax-exempt hospitals to demonstrate on an ongoing basis that they are in fact providing community benefits. Hospitals will assess what specific health needs their communities have, implement ways to meet those needs, and will then report what they are doing to the IRS. Any tax-exempt hospital that fails to comply with these requirements will be subject to a $\$ 50,000$ excise tax. ${ }^{160}$

The Affordable Care Act offers several methods for impacting care delivery in communities. Community Health Centers address care for the poor and underserved, while other programs are designed to assist the transition from an acute care provider to a post-acute care provider. Non-profit hospitals are now held accountable to monitor local health needs and report their activities to address these needs, or they will face financial penalties. The role of various healthcare providers within the community in connection with the provision, delivery and receipt of care is at the heart of the solution on both ends of the spectrum. Community-based care is at the heart of community accountability, with the hope that a dramatic shift in the way care is delivered will occur, that the quality of care improves and that the overall cost of care will decrease.

158 Patient Protection and Affordable Care Act of $2010 \mathrm{sec}$. $9007(\mathrm{a})(6), \S 501(\mathrm{r})(6)$ (codified as amended at 26 U.S.C. $\S 501(\mathrm{r})(6)$ (2013)).

159 Mary Crossley, Tax-Exempt Hospitals, Community Health Needs and Addressing Disparities, 55 How. L.J. 687, 701 (2012).

160 Patient Protection and Affordable Care Act of $2010 \S 9007(\mathrm{~b})$ (codified as amended at 26 U.S.C. $\$ 4959$ (2013)). 


\section{ACCOUNTABILITY TO GOVERNMENT}

Under the Affordable Care Act, regulators are now given broader enforcement authority to hold providers, practitioners, and patients accountable for the healthcare that is delivered and healthcare services that are sought. Various mechanisms under the Affordable Care Act focus squarely on improving quality, efficiency, transparency and integrity of the provision of healthcare in the United States. ${ }^{161}$ This increased accountability towards transparency and integrity among providers and practitioners works to ensure that, when the government is paying for a service, it can hold these constituencies responsible for the care provided and the level of transparency necessary to promote a more efficient healthcare system.

Because the federal government finances a considerable portion of healthcare in the United States, it is necessary for the government to 'get its money's worth' by holding participants accountable for the way monies are applied. ${ }^{162}$ Yet the manner of accountability is complicated. How can the federal government provide necessary incentives to health insurance companies to ensure that they are focusing on patient needs rather than emphasizing profitability at the patients' expense? What level of accountability is necessary to ensure practitioners, patients, and providers do not abuse the reimbursement that is available from the federal government? Has the Affordable Care Act implemented mechanisms to ensure accountability is consistent and fair?

161 See, e.g., Howard K. Koh \& Kathleen G. Sebelius, Promoting Prevention through the Affordable Care Act, 363 NEW ENG. J. MED. 1286 (2010); Robert P. Kocher \& Eli Y. Adashi, Hospital Readmissions and the Affordable Care Act: Paying for Coordinated Quality Care, 306 JAMA 1794 (2011); Tom Baker, Health Insurance, Risk, and Responsibility after the Patient Protection and Affordable Care Act, 159 U. PA. L. REV. 1577 (2011).

162 See generally Alyene Senger, Federal Spending on Health Care Doubles in the Next Decade, HeRITAGE Found. (Feb. 1, 2012, 3:18 PM), also available at http://blog.heritage.org/2012/02/01/federal-spending-onhealth-care-doubles-in-the-next-decade/. 
Although there are numerous ways in which the Affordable Care Act generates greater accountability, the government is holding health insurers, healthcare entities, physicians, and other providers accountable to create a more transparent healthcare system. First, the Affordable Care Act focuses on several matters that directly change the way that health insurance companies can do business. ${ }^{163}$ These provisions aim to ensure that health insurers are first and foremost accountable to their enrollees rather than their investors. Second, the Affordable Care Act implemented general fraud and abuse standards that impact many different healthcare actors who interact with federal healthcare programs. These new laws, funding, and programs act as general mechanisms to ensure healthcare participants are being compliant with the laws and making decisions that are in the best interest of all healthcare participants. Finally, the Affordable Care Act specifically implements laws and programs in which physicians are targeted. Ultimately, these laws aim to develop fewer conflicts and more transparency among physicians' decisions.

\section{A. Health Insurer Accountability}

Under the Affordable Care Act, the federal government is in the process of implementing sweeping changes, which may yield a considerably higher level of transparency and integrity between the federal government and health insurance companies. ${ }^{164}$ The need for accountability arises

163 See e.g., Guaranteed Availability of Individual Health Insurance Coverage to Certain Individuals with Prior Group Coverage, 42 U.S.C. $\S$ 300gg-41(a)(1) (2013); Group Health Plans and Health Insurance Issuers Relating to Coverage of Preventive Services Under the Patient Protection and Affordable Care Act, 77 Fed. Reg. 8725 (Feb. 15, 2012); Patient Protection and Affordable Care Act of $2010 \S 10406$ (codified as amended at 42 U.S.C. $\S 13951$ (2013)); Patient Protection and Affordable Care Act of $2010 \S 2719$ (codified as amended at 42 U.S.C. $\S 300 g g-19$ (2013)); Patient Protection and Affordable Care Act of $2010 \S 1331$ (codified as amended at 42 U.S.C. $\$ 18051$ (2013)).

164 See e.g., Jeffrey T. Kullgren et al., A Census of State Health Care Price Transparency Websites, 309 JAMA 2437 (2013); Anne Weiss, 
within insurer functions such as pricing, communication with enrollees, communication with providers, coverage issues, and a multitude of other instances. For example, health insurers, prior to the Affordable Care Act, used various tactics to deny coverage for an episode of care. This meant that a patient who was enrolled with a specific health insurer and who required an expensive form of care (which the insurer should cover) was denied coverage for the specific episode of care. Previously, the appeals process for such denials was not defined by federal law, but this has changed under the Affordable Care Act.

Another example of transparency and integrity is the concept of minimum coverage for insurance policies. Health insurance packages varied among insurers and products, and many times high-cost care would be covered by a basic policy but basic preventive care would not be covered. In some cases, an individual may assume that a routine checkup was covered, but the individual learned when the bill arrived that the basic preventative checkup was not covered under the policy. Variations on these types of problems have created a multitude of situations in which health insurance companies needed to be more transparent and accountable.

Health insurance pre-Affordable Care Act operated in ways in which it was not as necessary for the consumer to be actually involved in the financing process because employers generally shouldered this burden. ${ }^{165}$ In fact, as of 2004 , approximately $60 \%$ of the U.S. population received health insurance coverage through their employers. ${ }^{166}$

Transforming Care Through Transparency, HEALTH AFF. BLOG (Oct. 5, 2012), http://healthaffairs.org/blog/2012/10/05/transforming-carethrough-transparency/; U.S. Gov'T ACCOUNTABILITY OFF., GAO-11-791, REPort to CONGREsSional Requesters: Health CARE PRICE TRANSParency: MEANINGFUl PRICE INFORMation is Difficult FOR CONSUMERS to OBTAIN PRIOR to ReCEIVING CARE (2011), available at http://www.gao.gov/new.items/d11791.pdf.

165 Thomas Bodenheimer \& Kevin Grumbach, Paying for Health Care, 272 JAMA 634, 635-36 (1994).

166 Paul Fronstin, Uninsured Unchanged in 2004, but EmploymentBased Health Coverage Declined, 26 EMP. BENEFIT RES. INST. NOTES 2 (2005). 
However, individuals seeking to purchase insurance on the open market without the benefit of employer-sponsored coverage have long faced problems. ${ }^{167}$

For example, insurers often used the mechanism of preexisting conditions to refuse coverage to consumers on the individual market because those conditions increase the likelihood of claims. ${ }^{168}$ This resulted in a health insurance system in which consumers relied heavily on employers because they would be covered even with preexisting conditions ${ }^{169}$, while consumers in individual markets would not. This obstacle along with price transparency helped to develop a health insurance system in which there was little accountability between the government, insurers, and consumers.

To remedy the problem facing consumers seeking to purchase non-employer sponsored insurance coverage, the Affordable Care Act implemented several strategies that help curb this lack of accountability among the government, insurers, and consumers. First, the Affordable Care Act added several consumer protections for when consumers

167 Michelle M. Doty et al., Failure to Protect: Why the Individual Insurance Market is Not a Viable Option for Most U.S. Families, 63 COMMONWEALTH FUND 1 (2009), http://www.commonwealthfund.org/ / media/Files/Publications/Issue\%20Brief/2009/Jul/Failure\%20to\%20Prot ect/1300_Doty_failure_to_protect_individual_ins_market_ib_v2.pdf; Mary Mahon et al., New Report: Individual Health Insurance Market Failing Consumers, COMMONWEALTH FUND (July 21, 2009), http://www.commonwealthfund.org/ /media/Files/News/News\%20Releas es/2009/Jul/Failure\%20to\%20Protect\%20PR\%20FINAL\%2072109\%20re v2.pdf. ("Seventy-three percent of people who tried to buy insurance on their own in the last three years did not purchase a policy, primarily because premiums were too high. In addition, among adults with individual coverage or who tried to buy coverage in the past three years, 57 percent said it was very difficult or impossible to find coverage they could afford, 47 percent said it was very difficult or impossible to find a plan with the coverage they needed, and 36 percent were denied coverage or charged more because of a pre-existing condition, or had the condition excluded from their coverage.").

168 James P. Baker, Equal Benefits for Equal Work? The Law of Domestic Partner Benefits, 14 LAB. LAW. 23, 45 (1998).

169 Guaranteed Availability of Individual Health Insurance Coverage to Certain Individuals with Prior Group Coverage, 42 U.S.C. $\S$ 300gg-41(a)(1) (2013). 
deal with the insurance industry. ${ }^{170}$ In particular, there are now prohibitions on placing lifetime limits on coverage and on rescinding coverage once the limit has been met, which avoids the problem of loss of coverage for a high-cost health issue. ${ }^{171}$

For example, a toddler in need of a heart transplant exhausted her $\$ 1$ million lifetime maximum on her insurance policy after three weeks. ${ }^{172}$ As another example, a teenager diagnosed with a form of leukemia in 2007 reached his maximum limit in less than a year and was left with the option of a $\$ 600,000$ deposit or $\$ 500,000$ payment for a bone marrow transplant. 173 Although the family raised the necessary amount of funds, the young man died before he could receive the transplant. ${ }^{174}$ This problem is not an anomaly, because according to the Henry J. Kaiser Family Foundation, $22 \%$ of employees have caps of less than $\$ 2$ million. ${ }^{175}$

Next, with respect to the coverage of preventive benefits, the Affordable Care Act operates to hold more insurers accountable for covering the basic needs of individuals. ${ }^{176}$ According to a study performed by Northwestern University faculty and students in 2008, "many insurers choose not to cover preventive care and other treatments that have high

170 Patient Protection and Affordable Care Act: Preexisting Condition Exclusions, Lifetime and Annual Limits, Rescissions, and Patient Protections, T.D. 9491, 75 Fed. Reg. 37,188 (June 28, 2010) (codified at 26 C.F.R. pts. 54, 602, 29 C.F.R. pt. 2590, 45 C.F.R. pts. 144, $146,147)$.

171 Id.

172 Tom Murphy, Patients Struggle with Health Insurance Caps, L.A. Times (July 14, 2008), http://articles.latimes.com/2008/jul/14/ business/fi-lowcaps 14 .

${ }_{173}$ Health Insurance Caps Leave Patients Stranded, NBCNEWS.COM, http://www.nbcnews.com/id/25644309/ns/healthhealth_care/t/health-insurance-caps-leave-patients-stranded/\#.

UgfBNZK2M64 (last updated July 13, 2008, 1:29:36 PM).

174 Id.

175 Id.

176 Group Health Plans and Health Insurance Issuers Relating to Coverage of Preventive Services Under the Patient Protection and Affordable Care Act, 77 Fed. Reg. 8725, 8726 (Feb. 15, 2012). 
up-front costs."177 Beginning on September 23, 2010, health insurance companies are now required to provide minimum coverage that includes preventive care. ${ }^{178}$ In addition, many preventive services now are required to waive any coinsurance payments that were previously required. ${ }^{179}$ As of 2013, the Affordable Care Act has extended free preventive care to 71 million Americans. ${ }^{180}$

Another additional consumer protection promoting accountability relates to insurance coverage appeals processes. ${ }^{181}$ In particular, group health plan and health insurance issuers are now required to implement effective appeals processes allowing the enrollee notice and the chance to review their file. ${ }^{182}$ A 2008 study by the American Medical Association found that between 2.65\% and $6.8 \%$ of claims were denied; 183 however such denials often lacked any sort of notification or appeals process, which often led to reversals. ${ }^{184}$

177 Pat Vaughan Tremmel, Study Seeks Win-Win for Insurance Coverage for Preventive Care, NW. UNIV. NEWSCENTER (Jan. 15, 2008), http://www.northwestern.edu/newscenter/stories/2008/01/ insuranceprev.html.

178 See Key Features of the Affordable Care Act by Year, U.S. DEP'T HEALTH \& HUMAN SERVS., http://www.hhs.gov/healthcare/facts/timeline/ timeline-text.html (last visited Jan. 13, 2014).

179 Patient Protection and Affordable Care Act of 2010, Pub. L. No. 111-148, $\S 10406,124$ Stat. 119-1025 (2010) (codified as amended at 42 U.S.C. $§ 13951(2013))$.

180 Press Release, DeP't Health \& Human Servs., Affordable Care Act Extended Free Preventive Care to 71 Million Americans with Private Health Insurance (Mar. 18, 2013), available at http://www.hhs.gov/news/press/2013pres/03/20130318a.html (last revised Aug. 5, 2013).

181 Patient Protection and Affordable Care Act of $2010 \S 2719$ (codified as amended at 42 U.S.C. $\$ 300 \mathrm{gg}-19$ (2013)).

182 Guaranteed Availability of Individual Health Insurance Coverage to Certain Individuals with Prior Group Coverage, 42 U.S.C. $300 \mathrm{gg}-19$.

${ }_{183} T V$ Ad Overstates Health Insurance Denials, PoLitiFACT.COM (Sept. 18, 2009, 3:57 PM), http://www.politifact.com/truth-ometer/statements/2009/sep/18/health-care-america-now/tv-adoverstates-health-insurance-denials/.

184 See generally U.S. GoV'T ACCOUNTABILITY OFF., GAO-11-268, Report to THE SEcretary of Health and Human Services and THE 
The claim denial process was a problem because it left many individuals with little options but to pay for their care out-of-pocket. For example, a school administrator was denied coverage for her arthroscopic surgery when she underwent the surgery for bone spurs. ${ }^{185}$ The total bill for the surgery was $\$ 21,225.186$ Although the patient was eventually able to settle with the insurance company for less than the total cost, claim denial processes are a substantial issue with 100 million claims being initially denied per year. ${ }^{187}$

The Affordable Care Act implemented the minimum medical loss ratio for insurers to avoid perceived money grabs by insurance companies. ${ }^{188}$ In particular, this requires health plans to report the proportion of premiums spent on services for enrollees and providing a rebates to enrollees if the share of the premium spent on services is less than $85 \%$. ${ }^{189}$ The primary goal of this provision is to allow enrollees benefits, or rebates, when the services that were provided were less than $85 \%$ of the premiums paid. This requirement allows the government to provide additional accountability on health insurers to spend premiums ${ }^{190}$ on services to enrollees rather than corporate or shareholder benefits. Although this issue is controversial

Secretary of Labor: Private Health Insurance Data on APPLICATION AND COVERAGE DENIALS (2011), available at http://www.gao.gov/new.items/d11268.pdf.

185 Walecia Konrad, Fighting Denied Claims Requires Perseverance, N.Y. TIMES (Feb. 5, 2010), http://www.nytimes.com/ 2010/02/06/health/06patient.html?pagewanted=all\&_r=0.

186 Id.

187 Id.

188 Patient Protection and Affordable Care Act of 2010, Pub. L. No. 111-148, § 1331, 124 Stat. 119-1025 (2010) (codified as amended at 42 U.S.C. $\S 18051$ (2013)).

18942 U.S.C. 18051 (2013).

190 See generally Obamacare in Three Words: Saving People Money, WHITEHOUSE.GOV (July 18, 2013), http://www.whitehouse.gov/share/ health-care-rebate $(\$ 500,000,000$ in rebates were provided back to enrollees during 2012). 
to some, ${ }^{191}$ the end goal is to create a more accountable and transparent health insurance system.

\section{B. Fraud and Abuse Promoting Accountability}

The Affordable Care Act implemented several programs and laws in which the focus was on high-risk areas of fraud and abuse within healthcare. For fiscal year 2011, the Office of Inspector General was responsible for $\$ 4.1$ billion in recoveries, a global number that may not seem significant but its impact on individual providers can be substantial. 192 Fraud and abuse has been a primary issue for the federal government over the past twenty years; 193 however the Affordable Care Act implemented new efforts for increased enforcement and laws in which high-risk areas are further deterred from. ${ }^{194}$

With respect to the high-risk areas, the Affordable Care Act implemented several laws in which durable medical

191 Robert Book, Obama Touts False Benefits of Health Insurance Rebates, FORBES (July 18, 2013, 7:19 PM), http://www.forbes.com/sites/ theapothecary/2013/07/18/obama-touts-false-benefits-of-healthinsurance-rebates/ (explaining that the rebates are "not really savings because the MLR, perhaps unintentionally, actually encourages insures to increase premiums").

192 Dep'T of Health and Human SERvs. \& DeP'T OF Justice, Health Care Fraud and Abuse Control Program annual Report FOR FISCAL YEAR 2011 (2012), available at http://oig.hhs.gov/ publications/docs/hcfac/hcfacreport2011.pdf.

193 See generally Jennifer Staman, CONG. RESEARCH SERV., RS22743, Health CaRe Fraud aNd ABuse LaWs AFFECTING MEdicare AND MEDICAID: AN OVERVIEW (2010) ("A number of federal statutes aim to combat fraud and abuse in federally funded health care programs such as Medicare and Medicaid. Using these statutes, the federal government has been able to recover billions of dollars lost due to fraudulent activities."), available at http://www.adea.org/documents/ Section1/(1.3.1)-Anti-Kickback-Statute.pdf; see also Aaron M. Altschuler et. al., Health Care Fraud, 35 AM. CRIM. L. REV. 841, 843 (1998); Ann W. Morrison, An Analysis of Anti-Kickback and Self-Referral Law in Modern Health Care, 21 J. LEG. MED. 351, 354 (2000).

194 T.R. Goldman, Eliminating Fraud and Abuse, HEALTH AFF. (July 31, 2012), http://healthaffairs.org/healthpolicybriefs/brief_pdfs/ healthpolicybrief_72.pdf. 
equipment ("DME") is curbed. ${ }^{195}$ DME is reimbursed through Medicare Part B and includes such items as diabetic testing strips, canes, crutches, hospital beds, suction pumps, and many other types of equipment used to aid in an individual's care. ${ }^{196}$ This is a high-visibility area in terms of potential fraud, as Medicare spent more than $\$ 10$ billion in 2009 on DME, and more than half was improperly spent. ${ }^{197}$ Home healthcare is similarly ripe with opportunities for fraud and abuse. ${ }^{198}$ Other high-risk areas focused on were hospice fraud and nursing home fraud. By focusing on these high-risk areas, the Affordable Care Act deliberately operates to hold organizations accountable for necessary, but proper, care and to further the idea of transparency in healthcare.

In particular, the Affordable Care Act is designed to inhibit providers and companies from committing fraudulent acts at the outset. One way to accomplish this goal is to require more 'face-to-face' encounters at the beginning of a patient relationship. Previously, there were many ways in which fraud would occur in situations where face-to-face encounters were not a prerequisite to payment. Fraud occurred when DME companies provided DME to 'patients' who had died, or when DME suppliers provided equipment that was never requested. 199 As recently as July 2013, the Justice Department charged a DME supplier for Medicare fraud in relation to over $\$ 11$ million in fraudulent billings. ${ }^{200}$

195 Patient Protection and Affordable Care Act of 2010, Pub. L. No. 111-148, § 6407, 124 Stat. 119-1025 (2010) (codified as amended at 42 U.S.C. $\S \S 1395 \mathrm{f}, 1395 \mathrm{~m}, 1395 \mathrm{n}(2013))$.

196 Your Medicare Coverage: Durable Medical Equipment (DME) Coverage, MEDICARE.GOV, http://www.medicare.gov/coverage/durablemedical-equipment-coverage.html (last visited Dec. 28, 2013).

197 Durable Medical Equipment Fraud, NEB. DEP'T OF HEALTH AND HUMAN SERVS., http://dhhs.ne.gov/medicaid/Documents/

Fact_Sheet_DME_Fraud.pdf.

198 Patient Protection and Affordable Care Act of $2010 \S 6407$ (codified as amended at 42 U.S.C. $\$ \S 1395 \mathrm{f}, 1395 \mathrm{~m}, 1395 \mathrm{n}(2013)$ ).

199 Id.

200 Press Release, 13-840, U.S. DEP'T OF JUSTICE, Owner of California Medical Equipment Supply Company Found Guilty of $\$ 11$ Million Medicare Fraud Scheme (July 24, 2013), available at 
However, now, in order for an individual to receive DME, the individual must have a face-to-face encounter with a physician, nurse practitioner, clinical nurse specialist, or a physician assistant. 201 Such a simple requirement eliminates opportunities to provide DME to dead patients or to patients who never wanted the DME at all. This law also applies to home health services in which an individual must receive orders for home health services from a physician. ${ }^{202}$ In hospice facilities, the Affordable Care Act implemented a required visit pursuant to which a practitioner must certify that the resident is eligible for hospice through a face-toface meeting. 203

Finally, the Affordable Care Act also brought about changes intended to reduce opportunities for fraud in nursing homes. In particular, skilled nursing facilities must now operate a compliance program, and background checks are required for direct patient access employees. ${ }^{204}$ Although these high-risk areas required changes to address accountability and transparency among healthcare entities, the Affordable Care Act also brought about changes geared toward all providers and practitioners that interact with federal healthcare programs.

With respect to funding to enforce fraud and abuse laws, the Affordable Care Act has increased funding to identify and prosecute potential fraudulent activity. One of the primary mechanisms is an increase in funding for fraud enforcement efforts for the decade following enactment. ${ }^{205}$ Between 2011 and 2020, the Affordable Care Act has

http://www.justice.gov/opa/pr/2013/July/13-crm-840.html (last visited Dec. 28, 2013) ("The trial evidence showed that [the defendants] submitted more than $\$ 11$ million in fraudulent claims from Ibon and Bonfee to Medicare for expensive, high-end power wheelchairs, hospital beds, braces and other DME that customers either did not need or receive.")

201 Patient Protection and Affordable Care Act of $2010 \S 6407$ (codified as amended at 42 U.S.C. $\$ \S 1395 f, 1395 \mathrm{~m}, 1395 \mathrm{n}(2013)$ ).

202 Id.

203 Id. $\S 3132$ (codified as amended at 42 U.S.C. $\S 1395 f(2013)$ ).

$204 I d . \S 6201$ (codified as amended at 42 U.S.C. $\$ 1320 \mathrm{a}-7 I(2013)$ ).

205 Id. $\S 6402$ (codified as amended at 5 U.S.C. $\S 552 \mathrm{a}(2013)$ and scattered sections of 42 U.S.C.). 
increased funding by $\$ 10$ million annually. ${ }^{206}$ In addition, the Affordable Care Act provided mandatory appropriations of $\$ 1.7$ billion in both 2010 and 2011 to fund fraud enforcement through various agencies. ${ }^{207}$ These actions have greatly increased the enforcement mechanisms to catch fraud and abuse in federal healthcare programs. What is the goal of all of this spending? Recovery of additional funds to help pay for portions of the Affordable Care Act. ${ }^{208}$

In addition to funding, additional laws were created with respect to Anti-Kickback violations. The Anti-Kickback Statute is a powerful fraud enforcement mechanism because it relates to knowing violations in which people or organizations are seeking to commit fraud against federal healthcare programs. ${ }^{209}$ The statute prohibits knowingly and willfully paying or receiving payments for any service or treatment when the payment is made by a federally funded healthcare program such as Medicare or

206 Id.

207 Hearing on Efforts to Combat Health Care Fraud and Abuse Before the Subcomm. on Labor, Health and Human Servs., Education, and Related Agencies H. Comm. on Appropriations, 111th Cong. (2010) (statement of William Corr, Deputy Secretary, U.S. Department of Health and Human Services.), available at http://www.hhs.gov/asl/testify/2010/03/t20100304a.html (last revised June 18, 2013).

208 See id. ("The Obama administration is focused on reducing all improper payments in federal programs, whether the result of criminal intent, greed or inefficiencies. So the Fiscal Year (FY) 2011 Budget Request to the Congress covers all types of fraud and abuse, as well as other categories of improper payments. With this funding request, we will be adding resources to law enforcement and program oversight, as well as to program integrity operations in the Centers for Medicare \& Medicaid Services (CMS). To demonstrate our commitment, the FY 2011 Budget includes a record $\$ 1.7$ billion to fight waste, fraud, and other improper payments. This includes $\$ 561$ million in discretionary funding, a $\$ 250$ million increase over FY 2010. Projecting this discretionary investment over 10 years, together with new program authorities and administrative actions proposed in the budget, will save nearly $\$ 25$ billion in Medicare and Medicaid expenditures over 10 years.").

209 See generally Criminal Penalties for Acts Involving Federal Health Care Programs, 42 U.S.C. $§ 1320 a-7 b(b)$ (2013). 
Medicaid. ${ }^{210}$ This criminal act can result in a conviction if the defendant knowingly and willfully, solicits or receives remuneration in return for a referral. ${ }^{211}$ Because this is a criminal penalty, the penalties consist of $\$ 25,000$ and imprisonment for up to five years for each offense. ${ }^{212}$ Like many of these laws, there are many safe harbor provisions covering a variety of arrangements, including investment interests, sales of practices, malpractice insurance, contracts for space or equipment, advertisements and promotions, and many others. ${ }^{213}$ However, even the AntiKickback Statute can be tough to enforce because of the requirement to show knowing or willful violations.

The Affordable Care Act added a slight change to how the Anti-Kickback Statute applies, resulting in an easier road to establishing Anti-Kickback claims. In particular, the Affordable Care Act amends the Anti-Kickback Statute to provide that "a claim that includes items or services resulting from a violation constitutes a false or fraudulent claim for purposes of the" False Claims Act. ${ }^{214}$ Any violation of the Anti-Kickback Statute will now transform into a False Claim under the False Claims Act. This is important because it opens up the door to whistleblower provisions provided under the False Claims Act in which individuals may bring actions on behalf of the government (and share in any monetary recovery).215 To put the importance of this into perspective, the federal government

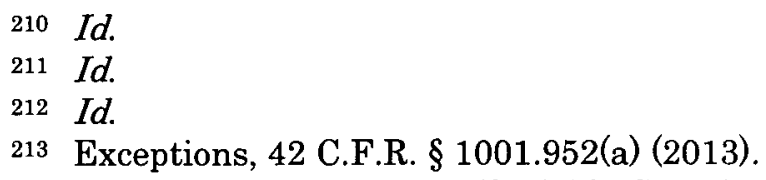

214 Patient Protection and Affordable Care Act of 2010, Pub. L. 111 $148, \S 6402,124$ Stat. $119 \cdot 1025$ (2010) (codified as amended at 5 U.S.C. $\S 552 \mathrm{a}$ (2013) and scattered sections of 42 U.S.C.).

215 False Claims Act, 31 U.S.C. \$§ 3729-33 (2013). See generally Geneva Campbell, Comment: Snitch or Savior? How the Modern Cultural Acceptance of Pharmaceutical Company Employee External Whistleblowing is Reflected in Dodd-Frank and the Affordable Care Act, 15 U. PA. J. Bus. L. 565 (2013); Timothy Stoltzfus Jost, Optimizing Qui Tam Litigation and Minimizing Fraud and Abuse: $A$ Comment on Christopher Alexion's Open the Door, Not the Floodgates, 69 WASH. \& LEE L. REV. 419 (2012). 
has recovered nearly $\$ 22$ billion under the False Claims Act between 1987 and 2008. ${ }^{216}$ Not only did the Affordable Care Act expand the ease in which a violation of the AntiKickback Statute may constitute a false claim, but the Affordable Care Act creates a stronger enforcement vehicle under the False Claims Act to pursue potential overpayments as well.

Under the False Claims Act pre-Affordable Care Act, the public disclosure bar prohibited individuals from filing suits based on fraudulent activity unless that individual was the original source of the information that provided the foundation of the suit. ${ }^{217}$ Under the Affordable Care Act, this concept was narrowed. In particular, these types of suits are barred now only when the same allegations were already publicly disclosed in a federal criminal, administrative, or civil hearing, or another form of federal hearing or investigation, or by the media. ${ }^{218}$ In addition, the original source definition was broadened to include any individual who has knowledge that is "independent and materially adds to the publicly disclosed allegations or transactions and who voluntarily provided the information to the government."219 By widening the road for whistleblowers, the Affordable Care Act will broaden the scope of claims brought under the False Claims Act.

\section{Physician Accountability and Conflicts of Interest}

In addition to the focus on health insurers, high-risk areas, and general fraud and abuse provisions, the Affordable Care Act has extended the focus of accountability and transparency to physicians. This expansion centers upon physician-owned hospitals, physician investment interests, disclosure requirements regarding the Stark Law,

216 U.S. DeP'T OF JUSTICE, FRAUD STATISTICS 1986-2008, available at http://www.justice.gov/opa/pr/2008/November/fraud-statistics19862008.htm (last visited Dec. 29, 2013).

21731 U.S.C. $\$ \S 3729-33$.

218 Patient Protection and Affordable Care Act of $2010 \S 10104(j)(2)$ (codified as amended at 31 U.S.C. $§ 3730$ (2013)).

21931 U.S.C. $\$ 3730$. 
and prescription drug samples. ${ }^{220}$ These provisions focus on a higher level of transparency within the practice of medicine, and an attempt to limit conflicts of interest. Although other laws such as the Stark Law and the AntiKickback Statute work to curb such abuses, these additional provisions provide substantial movement forward in a more transparent and accountable system.

With respect to physician-owned hospitals, these facilities expanded rapidly from 2002 to 2010.221 Specifically, there were forty-six physician-owned hospitals in 2002 , and that number ballooned to 265 by 2010.222 "For years critics have complained that when doctors invest in hospitals, conflicts of interest arise that could endanger patients and threaten the survival of general hospitals." 223 The issue is divisive, and others argue that physician-owned hospitals provide valuable tax revenue to the government. The Physician Hospitals of American reported that each physician-owned hospital paid $\$ 3$ million per year in taxes. $^{224}$ Although the issue of whether physicians should own hospitals has many critics on both sides, Congress, in passing the Affordable Care Act, effectively decided that physicians could no longer own hospitals. ${ }^{225}$

Under the Affordable Care Act, new physician-owned hospitals are forbidden, and existing physician-owned hospitals generally can no longer expand their facility capacity; however, hospitals may still be owned even after the law if they have a provider agreement prior to February

220 See generally Patient Protection and Affordable Care Act of $2010 \S \S 6001-05$ (codified as amended at 42 U.S.C. $\S \S 1395 \mathrm{nn}, 1320 \mathrm{a}-7 \mathrm{~h}$, 1320a-7i, 1320b-23 (2013)).

221 MEDICARE PAYMENT ADVISORY COMM'N, REPORT TO THE CONGRESS: PhYSICLAN-OWNED SPECIALTy HOSPITALS REVISITED $3-4$ (2006), available at http://www.medpac.gov/documents/ Aug06_specialtyhospital_mandated_report.pdf.

222 Id. at 6.

223 Should Doctors Own Hospitals?, BLOOMBERG Bus. WK. (Feb. 19, 2006), http://www.businessweek.com/stories/2006-02-19/should-doctorsown-hospitals.

224 Id. at 7.

225 Patient Protection and Affordable Care Act of $2010 \S 6001$ (codified as amended at 42 U.S.C. $§ 1395 \mathrm{nn}(2013)$ ). 
2010.226 This prohibition on the expansion or ownership of physician-owned hospitals largely dealt with conflict of interest issues. ${ }^{227}$

In addition to prohibiting physician-owned hospitals, the government has also attempted to deter conflicts of interests with respect to physicians' investment interests. ${ }^{228}$ This includes additional reporting requirements for physicians regarding their investment and ownership interests because physicians receive different forms of remuneration that may create conflicts of interest from medical device and pharmaceutical companies. ${ }^{229}$ Medical device and pharmaceutical companies must now report annually any investment and ownership interests a physician might have. ${ }^{230}$ The Affordable Care Act also requires that any gifts from medical device and pharmaceutical companies to physicians must be reported. ${ }^{231}$ This largely is meant to curb any conflicts that may arise when gifts may create an allegiance to a specific provider even though such supplies and services may not be medically necessary. 232

Physician accountability and transparency is also targeted with respect to medical imaging services. Under the Affordable Care Act, disclosure is required for physicians regarding medical imaging services that are excluded from the Stark in-office ancillary services

$226 I d$.

227 See generally Joshua E. Perry, Physician-Owned Specialty Hospitals and the Patient Protection and Affordable Care Act: Health Care Reform at the Intersection of Law and Ethics, 49 AM. BUS. L.J. 369 (2012).

228 Patient Protection and Affordable Care Act of $2010 \S 6002$ (codified as amended at 42 U.S.C. $\S 1320 \mathrm{a}-7 \mathrm{~h}$ (2013)).

229 Id.

$230 I d$.

231 Id. $\S 6004$ (codified as amended at 42 U.S.C. $\S 1320 \mathrm{a}-7 \mathrm{i}(2013)$ ).

232 See generally INST. OF MED., CONFLICT OF INTEREST IN MEDICAL RESEARCH, EduCATION, AND PRACTICE (Bernard Lo \& Marilyn J. Field, eds., 2009); MEDICARE PAYMENT ADVISORY COMM'N, REPORT TO THE CONGRESS: REFORMING THE DELIVERY SYSTEM (2008), available at http://www.medpac.gov/documents/jun08_entirereport.pdf. 
exception. ${ }^{233}$ Now, physicians that have ownership interests in these services must notify referred patients in writing of that interest. 234

These provisions regarding physicians have many different aims. First, physicians ultimately control the services patients require. Although there is a substantial amount of trust with physicians, the Affordable Care Act acts to curb any forms of conflict that may arise. Ultimately, by limiting potential conflicts, the government is attempting to create more accountability by these decision-makers. Second, the government recognized that steps such as these may be necessary to create a more transparent healthcare system. In part, these laws force physicians and other providers to make decisions dependent on whether a procedure is medically necessary rather than whether there are questions of allegiance, investment, or ownership interests. Finally, the ultimate goal is to develop a system in which patients, the government, and insurers can rely on physicians to make the right decisions.

Under the Affordable Care Act, third party payors, physicians, and many parties that interact with the healthcare system are now being held more accountable by the federal government. With respect to health insurance companies, the programs and laws implemented under the Affordable Care Act have far reaching implications for accountability and transparency within the insurance industry. In addition, the Affordable Care Act has also strengthened many of the existing fraud and abuse laws and added additional funding to curb healthcare fraud across the spectrum of healthcare participants. Finally, the focus on physicians is aimed at developing a transparent decision making process based on the best decision for the patient with the hope of eliminating conflicts. By creating transparency among insurers and physicians, and by strengthening the fraud abuse enforcement mechanisms, the federal government is now able to hold all healthcare

233 Patient Protection and Affordable Care Act of $2010 \S 6003$ (codified as amended at 42 U.S.C. § 1395nn (2013)).

234 Id. 
participants more accountable for their decisions in hopes of a more transparent and efficient system.

\section{Accountability Among Providers}

\section{A. A Brief History-U.S. Health System as a Fragmented Model}

The Affordable Care Act's idea of accountability encourages collaboration and requires providers to share in the costs and risks associated with health outcomes of a community of patients. However, the idea of an accountable group or large organization was less systematic and coordinated prior to the enactment and roll out of the Affordable Care Act. ${ }^{235}$ The story of the American healthcare system is one of many actors attempting to deliver care to patients throughout the country with little coordination. ${ }^{236}$ The United States healthcare system prior

235 Arthur Garson, Jr., The US Healthcare System 2010, 101 J. AM. HEART ASS'N 2015 (2000), available at http://circ.ahajournals.org/content /101/16/2015.full.pdf+html ("Ten years ago, the US healthcare system was declared 'broken,' and it has not improved. Fixes promised by managed care have not materialized. Premiums are rising. Hassles for patients and physicians abound. Nearly 45 million Americans are uninsured.").

236 Cathy Schoen et al., U.S. Health System Performance: $A$ National Scorecard, 25 HEALTH AFF. 457 (2006), available at http://content.healthaffairs.org/content/25/6/w457.full.pdf. The authors explain that "[c]oordination of care is particularly critical during transitions following hospital discharge. Yet hospitalized patients in the United States are less likely to have medications reviewed when discharged than is the case in several other countries. Across the United States, patients discharged from the hospital with $\mathrm{CHF}$ receive written discharge instructions only 50 percent of the time, on average, and there is an eighty-percentage-point spread between the top and bottom 10 percent of hospitals and a forty-percentage-point spread between the top and bottom 10 percent of states (64 percent versus 26 percent, data not shown). Patients hospitalized for mental health conditions often do not receive follow-up care within thirty days of discharge. On both CHF and mental illness indicators, there is a gap of twenty to thirty percentage points between national averages and rates achieved by the top group of hospitals or health plans. These shortcomings put patients at risk for complications and readmissions and raise the cost of care." Id. 
to the Affordable Care Act was disjointed and lacked these coordination and systematic accountability components. This lack of accountability and coordination reached to all providers, including hospitals, physicians, nurse practitioners, physician assistants and other healthcare providers.

Under the model of healthcare delivery pre-Affordable Care Act, the healthcare system created many inefficiencies and complexities. ${ }^{237}$ For example, in some areas of the country, Medicare spending was lower at the same time that a higher quality of care and better outcomes were achieved. ${ }^{238}$ Largely, these differences in geographic areas led some to argue that additional spending in higher cost regions was a product of greater use of hospitals, more frequent referrals and greater use of testing and minor procedures. ${ }^{239}$

In addition to the inefficiencies in overall costs regionally, U.S. healthcare spending highlights levels of waste in areas in which better coordination and accountability can reduce spending. ${ }^{240}$ Estimates suggest that up to $\$ 520$ billion in savings are possible due to hospital inefficiencies, unnecessary care, uncoordinated care, and avoidable care. ${ }^{241}$ In a study developed by the Centers for Disease Control and Prevention, it was estimated that the healthcare system lacked focus on serious preventive care services, which could prevent heart

237 E.A. McGlynn et al., The Quality of Health Care Delivered to Adults in the United States, 348 NEW ENG. J. MED. 2635 (2003) (acknowledging the complex fragmented healthcare delivery system).

238 Katherine Baicker \& Amitabh Chandra, Medicare Spending, the Physician Workforce, and Beneficiaries' Quality of Care, 23 HEALTH AFF. w184 (2004), available at http://content.healthaffairs.org/content/ early/2004/04/07/hlthaff.w4.184.full.pdf.

239 CONG. Budget OFFICE, GEOGRAPHIC VARIATION IN HEALTH CARE SPENDING (2008).

240 Waste Measurements, Economist (June 17, 2011, 3:02 PM), http://www.economist.com/blogs/dailychart/2011/06/us-health-carespending.

241 Id. 
disease and increased cancer risk. ${ }^{242}$ The overall lack of focus on preventive care, increasing accountability, and decreasing inefficiencies has resulted in many of the problems that compelled the clamoring for greater reform.

However, one of the largest problems with the pre-health reform delivery system related to the responsibility and accountability of individual providers to each other. For example, according to the Medical Group Management Association, nearly $70 \%$ of physicians were in their own practices rather than in hospitals in 2005. ${ }^{243}$ Physicians often preferred the independence associated with their own practices rather than to be subject to the oversight of the large local hospital, which increasingly is a subsidiary organization to a much larger health system entity. Independence and collaboration are often at a crossroads.

This lack of collaboration may have been to the detriment of coordinated care, but collaboration and cost containment may not carry the link that was assumed. Consolidation of physician practices has yet to yield lower costs. ${ }^{244}$ In fact, in many areas, consolidation may be increasing coordination of care but also increasing the costs of healthcare. ${ }^{245}$

Another day-to-day operational issue among providers is the necessary collaboration between physicians, nurse practitioners, and physician assistants. ${ }^{246}$ With an additional 30 to 33 million newly-insured people seeking

242 CTRS. For Disease ConTrol AND PREVEnTION, USE OF SELECTED Clinical Preventive Services AMONg Adults - United States, 20072010, (2012), available at http://www.cdc.gov/mmwr/pdf/other/su6102. pdf.

243 Gardiner Harris, More Doctors Giving Up Private Practices, N.Y. TIMES (Mar. 25, 2010), http://www.nytimes.com/2010/03/26/ health/policy/26docs.html?pagewanted=all\&_r=0.

244 Id.

245 Robert A. Berenson et al., Unchecked Provider Clout in California Foreshadows Challenges to Health Reform, 29 HEALTH AFF. 1, (2010), available at http://content.healthaffairs.org/content/early/ 2010/02/25/hlthaff.2009.0715.full.pdf.

246 Lora Hine, Nurse Practitioners Help Fill Critical Shortage of Health Care Professionals, CHRON (June 21, 2013), available at http://www.chron.com/health/article/Nurse-practitioners-help-fillcritical-shortage-4614372.php (last updated June 21, 2013, 11:34 AM). 
care once the Affordable Care Act is fully implemented in 2016, more people will be sitting in waiting rooms of doctor's offices for appointments. ${ }^{247}$ With this increase in patients, physician groups and other trade organizations have also analyzed their ability to provide care. ${ }^{248}$ According to the Association of American Medical Colleges, there will be a shortage of 91,500 physicians by 2020 , resulting in various practitioners needing to work together to service communities. ${ }^{249}$ Overall, the Affordable Care Act has impacted a system in which nurse practitioners and physician assistants previously had less autonomy. But the new populations seeking care will require these nonphysician practitioners to work and collaborate with physicians.

Passage of the Affordable Care Act means that millions more people are covered, but will there be enough providers to take care of these additional patients?250 Do we expand the scope of practice for other practitioners such as physician assistants or nurse practitioners? Do we change reimbursement models to include other providers as primary care providers? Should physicians lead the specialists in the delivery of care? These questions each have divisive answers from all sides. The Affordable Care Act charged through these roadblocks and acted as an impetus to ensure that these different providers work together to better coordinate care for millions across the country.

247 See Rachel Nardin et al., The Uninsured After Implementation Of The Affordable Care Act: A Demographic And Geographic Analysis, HEALTH AFF. BLOG (June 6, 2013), http://healthaffairs.org/blog/2013/06/ 06/the-uninsured-after-implementation-of-the-affordable-care-act-ademographic-and-geographic-analysis/.

248 Physician Shortages to Worsen Without Increases in Residency Training, AM. ASS'N MED. Cs., https://www.aamc.org/download/286592/ datal.

249 Id.

250 David Troxel, Op-Ed., Doctor Shortage Looms in Health Care Reform, LiveScience (June 14, 2013, 6:14 PM), http://www.livescience.com/37468-doctor-shortage.html. 


\section{B. Promoting Accountability Among Providers}

The enactment of the Affordable Care Act has resulted in several areas that impact, either directly or indirectly, the accountability of providers and practitioners. Directly, the Affordable Care Act works to strengthen primary care for the communities that providers serve. The impact on primary care requires providers to be accountable for preventing healthcare events rather than simply treating illnesses and events once they occur. Also, by strengthening primary care, the Affordable Care Act has brought to the forefront delivery models in which providers must work together to care for patients through patient centered medical homes. Finally, the Affordable Care Act implemented incentives for physicians, nurse practitioners, and other providers to choose primary care rather than other higher paying specialties addressing the current fragmentation among provider specialties.

With respect to patient care models, the Affordable Care Act strengthens cooperation and collaboration among providers by incentivizing teamwork and accountability. One of the primary examples of these types of models includes increased funding for community health centers. ${ }^{251}$ In many community health centers, providers are reimbursed at the same rates, unlike in other settings, and teamwork, accountability, and collaboration are the only effective means in which these organizations can service their communities. Finally, one of the largest and most well-known changes that impacts the accountability and collaboration of providers relates to the implementation of accountable care organizations. ${ }^{252}$ In these organizations, the goals is to align incentives so that providers can share

251 Public Health Service Act, Pub. L. No. 78-410, § 330, 58 Stat. 682 (1944) (codified as amended at 42 U.S.C. $\S 254 \mathrm{~b}$ (2013)), amended by Patient Protection and Affordable Care Act of 2010, Pub. L. No. 111148, § 10406, 124 Stat. 119-1025 (2010) (codified as amended at 42 U.S.C. $\S 254 \mathrm{~b}-2$ (2013)), amended by Healthcare and Education Reconciliation Act, Pub. L. 111-152, 124 Stat. 1029-84 (2010).

252 Patient Protection and Affordable Care Act of $2010 \S 3022$ (codified as amended at 42 U.S.C. $§ 1395 \mathrm{jjj}$ (2013)). 
in the savings brought about by higher quality and more coordinated care.

\section{Strengthening "Primary Care"}

The Affordable Care Act has instituted collaboration and accountability among providers and practitioners through various incentive programs that strengthen primary care. By strengthening primary care services in the healthcare system, the Affordable Care Act implemented a standard of services that will provide substantial benefits to facilitating coordination across the continuum of care. Through the funding of patient centered medical homes, new payment models and additional funding for the training of many different practitioners, the Affordable Care Act acts to reach these goals.

"Primary care" is a term often misunderstood by the public, although most patients commonly experience it whenever they receive treatment from a family physician. If someone has ever sought treatment for symptoms of the flu, needed routine tests, or required education regarding his or her healthcare, he or she has likely experienced "primary care." One definition is that "primary care is the provision of integrated, accessible health care services by clinicians who are accountable for addressing a large majority of personal health care needs, developing a sustained partnership with patients, and practicing in the context of family and community."253 However, other definitions are much more expansive, such as the definition from the American Academy of Family Physicians:

Primary care is that care provided by physicians specifically trained for and skilled

253 COMM. ON THE FUTURE OF HEALTH CARE WORKFORCE FOR OLDER AMS., Inst. MED. OF THE NAT'L ACADEMIES, Retooling for an Aging America: Building the Health Care Workforce 27 (2008), available at http://www.iom.edu/ /media/Files/Report\%20Files/2008/Retooling-foran-Aging-America-Building-the-Health-Care-Workforce/

ReportBriefRetoolingforanAgingAmericaBuildingtheHealthCareWorkfo rce.pdf. 
in comprehensive first contact and continuing care for persons with any undiagnosed sign, symptom, or health concern (the "undifferentiated" patient) not limited by problem origin (biological, behavioral, or social), organ system, or diagnosis. Primary care includes health promotion, disease prevention, health maintenance, counseling, patient education, diagnosis and treatment of acute and chronic illnesses in a variety of health care settings (e.g., office, inpatient, critical care, long-term care, home care, day care, etc.). Primary care is performed and managed by a personal physician often collaborating with other health professionals, and utilizing consultation or referral as appropriate. Primary care provides patient advocacy in the health care system to accomplish cost-effective care by coordination of health care services. Primary care promotes effective communication with patients and encourages the role of the patient as a partner in health care. ${ }^{254}$

Here, this definition specifically refers to the role of physicians. However, the role of primary care and the various types of healthcare providers delivering that care is substantially changing.

The Affordable Care Act's first method of strengthening primary care and accountability of providers deals with the implementation and support of patient-centered medical homes. The Affordable Care Act established a Center for Medicaid and Medicare Innovation to develop care models "promoting broad payment and practice reform in primary care, including the patient-centered medical home

254 Primary Care, AM. ACAD. FAM. PHYSICIANS, http://www.aafp.org/online/en/home/policy/policies/p/primarycare.html (last visited Dec. 29, 2013). 
models." 255 This promotes models in which "a close relationship between care coordinators, primary care practitioners, specialist physicians, community-based organizations, and other providers of services and suppliers" can work together. ${ }^{256}$

In particular, patient-centered medical homes "include enhanced patient access to a regular source of primary care, stable and ongoing relationships with a personal clinician who directs a care team, and timely, well-organized health services that emphasize prevention and chronic care management."257 This concept, although fluid in its process and delivery, has been estimated to reduce spending by an estimated $\$ 175$ billion through 2020.258 Generally though, the patient-centered medical home concept develops strong accountability and collaboration between various providers.

One of the first patient-centered medical home practice sites was set in the State of Washington. ${ }^{259}$ The Journal of Ambulatory Care Management published a case study about the implementation of such a concept. ${ }^{260}$ The model was spread to a set of twenty-six primary care practices in fourteen months, reaching more than 600,000 patients and ranging to both urban and rural settings. ${ }^{261}$ The various clinics implemented staffing changes, which increased the roles of physician assistants, nurse practitioners, registered

255 Patient Protection and Affordable Care Act of $2010 \S 3021(\mathrm{a})$ (codified as amended at 42 U.S.C. $§ 1315$ a (2013)).

256 Id.

257 Karen Davis et al., supra note 76, at 1201-03.

258 The Path to a High Performance U.S. Health System: A 2020 Vision and the Policies to Pave the Way, CoMmonWEalth Fund CoMm'N ON High PERFORMANCE HEALTH SYS. (2009), http://www.commonwealthfund.org/ /media/Files/Publications/Fund\%20 Report/2009/Feb/The\%20Path\%20to\%20a\%20High\%20Performance\%20 US\%20Health\%20System/1237_Commission_path_high_perform_US_hl t_sys_WEB_rev_03052009.pdf.

259 Clarissa Hsu et al., Spreading a Patient-Centered Medical Home Model, 35 J. AMBULATORY CARE MGMT. 99, available at https://primarycare.hms.harvard.edu/sites/default/files/J\%20Amb\%20Ca re\%20Mgmt\%202012\%20Case\%20Study_1.pdf (last visited July 18, 2013).

260 Id.
261 Id. at $100-01$. 
nurses, and pharmacists, in general nearly doubling their numbers in practices led by physicians. ${ }^{262}$

In another report analyzing the results of a patientcentered medical home, the Commonwealth Fund formulated a report discussing a pilot project in Pennsylvania. ${ }^{263}$ After one year of the study, impressive improvements showed a $20 \%$ reduction in hospital admissions and a $12 \%$ reduction in readmission rates. ${ }^{264}$ One impediment to the establishment of such homes is that of collaboration ${ }^{265}$ among providers; however the amount of collaboration and accountability among providers has increased substantially, and, under the guidance of the Affordable Care Act, this accountability among providers has yielded impressive results.

Another avenue in which the Affordable Care Act has both strengthened primary care and instituted accountability among providers is through incentives to multiple types of primary care practitioners. First, the Affordable Care Act instituted accountability among providers by defining "primary care provider" in professionneutral terms (i.e., not only physicians). Under the Affordable Care Act, a "primary care provider" means:

a clinician who provides integrated, accessible health care services and who is accountable for addressing a large majority of personal health care needs, including providing preventive and health promotion services for men, women, and children of all ages, developing a sustained partnership with patients, and practicing in the context of family and

262 Id. at 101-05.

263 Hearing on "Person-Centered Care: Reforming Services and Bringing Older Citizens Back to the Heart of Society" Before the Special S. Comm. on Aging, 110th Cong. (2008) (Invited testimony by Melinda K. Abrams, Assistant Vice President, The Commonwealth Fund).

264 Id.

265 See Andis Robeznieks, Sore Subject: Nurses React as AAFP Report Backs Doctor-Led Medical Homes, ModernHealthcare.com (Oct. 6, 2012), http://www.modernhealthcare.com/article/20121006/ MAGAZINE/310069966. 
community, as recognized by a State licensing or regulatory authority, unless otherwise specified in this section. ${ }^{266}$

This is significant because one step in developing a system in which providers and practitioners work together relates to defining those providers.

\section{Payment Models Promoting Accountability Among Providers}

However, payment models also impact the ways in which providers will work together to strengthen primary care and develop more accountability among their team. The Affordable Care Act created the Incentive Payment Program for Primary Care Services. ${ }^{267}$ This payment incentive applies to primary care physicians specializing in family medicine, internal medicine, geriatric medicine, or pediatric medicine. ${ }^{268}$ It also applies to nurse practitioners, clinical nurse specialists, and physician assistants who provide at least $60 \%$ of their charges in primary care. ${ }^{269}$ In other words, physicians and non-physicians are targeted for the incentive.

The payment incentive provides a $10 \%$ increase in payment for primary care practitioners for allowable primary care services. ${ }^{270}$ By aligning incentives among various providers, the implementation of payment incentive programs ultimately requires various practitioners to be accountable to one another in the provision of primary care services.

In addition to increased reimbursements that incentivize provider cooperation and collaboration, the Affordable Care

266 Patient Protection and Affordable Care Act of 2010, Pub. L. No. 111-148, §5405, 124 Stat. 119-1025 (2010) (codified as amended at 42 U.S.C. $§ 280 \mathrm{~g}-12(\mathrm{a})(3)(B)(2013))$ (emphasis added).

267 Id. $\S 5501(\mathrm{a})$ (codified as amended at 42 U.S.C. $\S \S 13951,1395 \mathrm{~m}$, $\left.1395 w^{-4}(2013)\right)$.

$268 I d$.

$269 I d$.

$270 I d$. 
Act implemented various funding opportunities for increasing the healthcare workforce. ${ }^{271}$ First, funding for the National Health Service Corps was permanently authorized. ${ }^{272}$ In particular, the funding allows student loan repayments for physicians, dentists, nurse practitioners, midwives, and physician assistants whom agree to serve in designated Health Professional Shortage Areas. ${ }^{273}$ These areas include both rural and underserved areas in which providers are accountable to one another for maintaining the health of communities in which health services are scarce. ${ }^{274}$

Also, the Affordable Care Act implemented funding for primary care training programs for physicians, nurse practitioners, and physician assistants. ${ }^{275}$ First, the Affordable Care Act authorized grants to support training programs to create academic units to enhance interdisciplinary training for both physicians and physician assistants. ${ }^{276}$ These training programs apply to medical schools and physician assistant training programs associated with academic institutions. ${ }^{277}$ Also, the Affordable Care Act specifically included funding for nurse practitioner training programs to increase nurse practitioners in the workforce. ${ }^{278}$ The goal is two-fold. First, this inevitable relates to increasing the workforce, but more importantly the Affordable Care Act addresses that

271 C. Stephen Redhead et AL., Cong. Research SerV., R41390, Discretionary Funding IN THE PATIENT PRotection AND AFFoRDABLE CARE ACT (2011), available at http://www.ncsl.org/documents/health/ DisFundingACA.pdf.

272 Patient Protection and Affordable Care Act of $2010 \S 5207$ (codified as amended at 42 U.S.C. $\$ 254 q(2013)$ ).

273 Id.

274 See generally Shortage Designation: Health Professional Shortage Areas \& Medically Underserved Areas/Populations, HEALTH RES. \& SERVS. ADMIN., U.S. DEP'T HEALTH \& HUM. SERVS., http://www.hrsa.gov/shortage/ (last visited Dec. 29, 2013).

275 Patient Protection and Affordable Care Act of $2010 \S \S 5301$, 5312 (codified as amended at 42 U.S.C. $\$ \S 293 \mathrm{k}, 298 \mathrm{~d}(2013)$ ).

276 Id. $\S 5301$ (codified as amended at 42 U.S.C. $\$ 293 \mathrm{k}(2013)$ ).

277 Id.

$278 I d . \S 5312$ (codified as amended at 42 U.S.C. $\S 298 \mathrm{~d}(2013)$ ). 
multiple providers must be trained in primary care to service communities together.

Finally, the Affordable Care Act authorized family nurse practitioner demonstration programs. ${ }^{279}$ Under these demonstration programs, nurse practitioners will be trained as primary care providers in Federally Qualified Health Centers and Nurse-Managed Health Clinics. ${ }^{280}$ The Health Resources and Services Administration explained that this support in Nurse-Managed Health Clinics will "improve access to primary care . . . [and] serve as primary care access points in areas where primary care providers are in short supply."281 These demonstration programs further highlight the Affordable Care Act's incentives to create accountability among various practitioners.

\section{E. Organizational Accountability}

In addition to the Affordable Care Act incentivizing teamwork and accountability among practitioners through payment models and training programs, the Affordable Care Act also addresses accountability through incentivizing organizations to challenge practitioners to collaborate and provide care more efficiently with one another. In particular, the Affordable Care Act focused efforts on organizational change to promote accountability not only between individual practitioners and their employers, but also between the practitioners themselves. The Affordable Care Act does this in two important ways. First, the Affordable Care Act has instituted change through additional funding for CHCs. Second, the Affordable Care Act has developed new methods of care delivery through the creation of ACOs.

279 Id. $\S 5316$ (codified as amended at scattered sections of 42 U.S.C.).

280 Id.

281 See Nurse Managed Health Clinics (NMHC), HEALTH RES. \& Servs. ADmin., U.S. DEP'T Health \& Hum. SERVS., http://bhpr.hrsa.gov/nursing/grants/nmhc.html (last visited Dec. 29, 2013). 
According to the Health Resources and Services Administration, CHC's "have become the essential primary care medical home for millions of Americans including some of the nation's most vulnerable populations."282 Specifically, the Affordable Care Act authorizes operating grants to CHCs throughout the United States to furnish comprehensive primary care services to patients, regardless of their ability to pay. ${ }^{283}$ Facilities such as these offer a substantial opportunity to facilitate change in the ways in which practitioners interact and provide accountability to one another. For example, according to the Center for Studying Health System Change, FQHCs support this interaction "especially through their primary care teams of physicians and midlevel providers, such as nurse practitioners - and PPACA provisions will likely support their continued role." 284

Finally, the Affordable Care Act institutionalized a care model that requires practitioners and providers to be accountable to one another. This care model is known as an ACO developed under the Medicare Shared Savings Program. ${ }^{285}$ Indeed, the word "accountable" itself is embedded within the very name of this model. This is notable because it highlights the level of focus placed on accountability.

The goal of ACOs in the Medicare Shared Savings Program is for "groups of providers of services and suppliers meeting criteria specified by the Secretary [to] work together to manage and coordinate care for Medicare feefor-service beneficiaries through an accountable care

282 The Affordable Care Act and Health Centers, Health RES. \& SERVS. ADMIN., U.S. DEP'T HEALTH \& HUM. SERVS., http://bphc.hrsa.gov/about/healthcenterfactsheet.pdf.

283 Patient Protection and Affordable Care Act of 2010, Pub. L. No. 111-148, $\S 5601,124$ Stat. 119-1025 (2010) (codified as amended at 42 U.S.C. $§ 254 b(2013))$.

284 Aaron Katz et al., $A$ Long Winding Road: Federally Qualified Health Centers, Community Variation and Prospects Under Reform, 21 Center for Studying Health Sys. Change: Res. Brief 1, (2011), available at http://www.hschange.com/CONTENT/1257/1257.pdf.

285 Patient Protection and Affordable Care Act of $2010 \S 3022$ (codified as amended at 42 U.S.C. § 1395jjj (2013)). 
organization."286 However, the definition of an ACO is a fluid concept in that there are multiple approaches. Generally, though, according to the National Institute for Health Care Reform, "ACOs will constitute groups of providers-physicians, other clinicians, hospitals or other providers-that together provide care and share accountability for the cost and quality of care for a population of patients." 287

Some associate the ACO model with current business models in different industries. Harold Miller, president and CEO of the Network for Regional Healthcare Improvement and executive director of the Center for Healthcare Quality \& Payment Reform in Pittsburgh, explains that we should "think of it as buying a television" in that:
A TV manufacturer like Sony may contract with many suppliers to build sets. Like Sony does for TVs . . . an ACO would bring together the different component parts of care for the patient - primary care, specialists, hospitals, home health care, etc. ${ }^{288}$

However, Miller notes, "ACOs will need to prove that the overall health care product they're creating does work better and costs less in order to encourage patients and payers to buy it." 289

The ACO model is unique in that it provides "financial incentives for broad cost containment and quality

$286 I d$.

287 Timothy K. Lake et al., Lessons from the Field: Making Accountable Care Organizations Real, NAT'L INST. FOR HEALTH CARE REFORM (Jan. 2011), available at http://www.nihcr.org/AccountableCare-Organizations.html.

288 Jenny Gold, FAQ On ACOs: Accountable Care Organizations, Explained, KaISER HEALTH NEws (Aug. 23, 2013), http://www.kaiserhealthnews.org/Stories/2011/January/13/ACOaccountable-care-organization-FAQ.aspx.

289 Id. 
performance across multiple sites of care."290 Thus there is now a financial incentive for primary care providers, specialists, and hospitals to work in a more integrated and cost-effective way. This includes new payment approaches aimed at sharing the cost between multiple providers ending in one common billing approach. ${ }^{291}$ Generally, an ACO will share responsibility for treating a group of patients. These shared and collective approaches create a system built on changing the way healthcare is delivered in the United States.

The National Institute for Health Care Reform analyzed seven healthcare organizations developing as ACOs. In this study, the organizations included "three integrated delivery systems, one physician-hospital organization ( $\mathrm{PHO}$ ), two medical groups - one large and one small group owned by a hospital - and one management services organization (MSO) affiliated with four independent practice associations."292 The study itself analyzed some of the major challenges that current systems are facing when attempting to transition to the ACO model. However, it is important to note that each of these organizations are quite different from one another, highlighting the flexibility needed when transitioning to an ACO model.

Nonetheless, the study resulted in four major challenges to these changes. First, funding was a major issue for each of these systems. ${ }^{293}$ The main problem is that the "improvements required substantial investment, both in time and money. Many funded these activities through existing reserves, while others . . . applied for and received grant funding."294 This creates a risk where certain systems do not have the capital to make these changes, and where others have utilized grant allocation to the maximum possible degree. Second, these organizations experienced a

290 Marsha Gold, Accountable Care Organizations: Will They Deliver?, MATHEMATICA POL'Y RES., INC. 1 (2010), available at http://www.mathematica-mpr.com/publications/pdfs/health/ account_care_orgs_brief.pdf.

291 Id.

292 Lake et al., supra note 287.

293 Id.

294 Id. 
huge amount of resistance to change. ${ }^{295}$ Generally, this is an internal issue that is challenging within any organization that is changing. However, the model itself necessitates change.

Other challenges facing the transition were potential disruptions to productivity and limited infrastructure to pursue these changes. ${ }^{296}$ The issue of disruptions to productivity was a major issue because the process required changes in workflow and different staff responsibilities. ${ }^{297}$ Additionally, infrastructure issues were fueled by the lack of ability to measure and track performance. ${ }^{298}$ Systems explained that it was necessary to use reliable data at all times; however, privacy issues required legal advice to continue with the transition. ${ }^{299}$ Nonetheless, throughout United States healthcare history, there have been varying models aimed at minimizing costs. This current model represents a major transition and the first step towards reaching the goal of accountability among providers, practitioners, and organizations.

A more recent report regarding the Pioneer ACO Program described the successes and pitfalls of some of the first ACOs organized under the Affordable Care Act. 300 Under the Pioneer ACO Program, thirty-two ACOs were formed to provide care for more than 669,000 beneficiaries. ${ }^{301}$ Overall, under these ACOs, costs grew by $0.3 \%$ in 2012 compared to 0.8 for similar beneficiaries. ${ }^{302}$ These ACOs earned over $\$ 76$ million for their efforts in cost

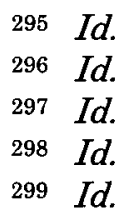

300 Press Release, Ctrs. for Medicare \& Medicaid Servs., Details for Title: Pioneer Accountable Care Organizations Succeed in Improving Care, Lowering Costs (July 16, 2013) [hereinafter Press Release, CMMS], available at http://www.cms.gov/Newsroom/

MediaReleaseDatabase/Press-Releases/2013-Press-Releases-Items/201307-16.html (last visited Dec. 29, 2013).

301 Id.; Lake et al., supra note 287.

302 Press Release, CMMS, supra note 301; Lake et al., supra note 287. 
savings; however two ACOs shared losses totaling $\$ 4.0$ million. ${ }^{303}$

Although the fragmented United States healthcare systems continues to experience change, the Affordable Care Act helped institute more accountability among the many players in the healthcare service industry. The Affordable Care Act implemented laws that impact the way teams of providers work together to provide care. In addition, primary care has been a focus point within the legislation that further allows providers the ability to work together and remain accountable to each other. Finally, the Affordable Care Act provides the proper incentive through payment models and organizational accountability to influence drastic changes in the ways in which providers, practitioners, and organizations interact.

\section{CONCLUSION}

The public's perception of the Affordable Care Act centered around the "hot button" issues. These included the "individual mandate," whether the federal government had the constitutional authority to require citizens to purchase health insurance, issues of health insurance exchanges and employer participation in health insurance. Aside from these more public topics, the subtle shift toward an accountable system designed to lower cost and improve quality appears to be lost in this debate, or at the very least muffled. Also missing in this conversation is the very word in which the legislation was designed to symbolize: "accountability."

In many ways, the Affordable Care Act's aims are more about requiring accountability among healthcare participants than about the publicly-discussed issues in which talk shows have developed sound bytes and political parties have been divided. Of all of the changes effectuated under the Affordable Care Act, accountability will become the benchmark for evaluating whether providers, patients, and the federal government have pursued the proper course

303 Press Release, CMMS, supra note 301; Lake et al., supra note 287. 
in the twenty-first century. It is these lesser-known "accountability" provisions that offer the hope of shifting the healthcare system into a more efficient and accountable organism. The need for decreasing costs, increasing quality, and expanding access can only be met with accountability because, without groups partnering together, patients holding their providers accountable, and the government ensuring a more transparent system, the integrity of the healthcare system cannot be maintained. The hope of an improved, sustainable healthcare delivery system, where improved healthcare is available for individuals and larger populations at a per-capita lower cost, is built upon a sustainable foundation: accountability. 
